\title{
Typecasting prospective Au-bearing sedimentary lithologies using sedimentary geochemistry and Nd isotopes in poorly exposed Proterozoic basins of the Tanami region, Northern Australia
}

\author{
Alexis Lambeck ${ }^{1,2 *}$ \\ David Huston ${ }^{2}$ \\ Karin Barovich $^{1}$ \\ ${ }^{1}$ Centre for Tectonics Resources and Exploration University of Adelaide, Adelaide, SA, 5005 \\ * Corresponding author e-mail: Alexis.Lambeck@ga.gov.au \\ ${ }^{2}$ Geoscience Australia GPO Box 378, Canberra, ACT, 2601
}

\begin{abstract}
The development of a regional stratigraphy in Palaeoproterozoic basins within the Tanami region, Northern Australia has been hindered by the difficulty of discriminating sedimentary units and facies across this isolated and poorly exposed basin. A regional stratigraphy is important as it provides constraints on sedimentary basin evolution and assists in gold exploration. Gold is known to be more concentrated in certain rock formations. Based on Nd isotopes and whole-rock geochemistry, five main sedimentary events have been identified in the Tanami region. Some sedimentary units were derived from homogeneous local sources whereas others contain evidence of a well-mixed fine-grained remote provenance. Within the basins, major gold-bearing lithologies are characterised by mafic source indicators: (1) high $\mathrm{Cr} / \mathrm{Th}$ ratios; (2) low Th/Sc ratios; (3) low (La/Yb) PAAS ratios relative to Post-Archaean Average Shale (Taylor and McLennan 1985); (4) Eu anomalies equal to $\sim 1$ and, (5) distinctive ranges in initial $\varepsilon_{\mathrm{Nd}}$ values. Potential future exploration target areas have been identified in the Tanami region at the Cashel and Sunline prospects using these geochemical parameters.
\end{abstract}

Key words Nd isotopes, geochemistry, Tanami, lode-gold, exploration, Paleoproterozoic

\section{Introduction}

The Tanami region is a poorly exposed, mostly Paleoproterozoic province within Northern Australia that hosts a number of significant gold deposits (Fig. 1) (Plumb et al. 1990; Smith et al. 1998; Huston et al. 2007; Bagas et al. 2009). The Callie deposit is the largest (6.0 Moz Au) and is hosted by black mudstones of the Dead Bullock Formation (Smith et al. 1998). Effective exploration of the Tanami region, however, has been severely hampered by poor knowledge of the regional stratigraphy. It is difficult to identify and correlate exposed packages of poorly-sorted sandstones, siltstones and black mudstones separated by large regions of regolith cover (Blake et al. 1979; Hendrickx et al. 2000; Crispe et al. 2007; Huston et al. 2007).

Lode-gold provinces such as the Yilgarn and Superior cratons host gold in a variety of lithologic types and structural settings (Hodgson 1993). In contrast to these regions, two of the three major goldfields in the Tanami region the Granites and Dead Bullock Soak goldfields, are hosted exclusively by carbonaceous or iron-rich sedimentary units (Huston et al. 2007). Smaller sediment-hosted gold deposits in the Tanami region include Oberon, Coyote and Minotaur. Huston et al. (2007) calculated that sediment-hosted gold deposits contain 77\% of the Tanami gold resource, (carbonaceous sedimentary rocks 61\%, banded iron formation 16\%). Given the lack of outcrop and the complex geophysical character of the lithology types, this paper focuses on sedimentary geochemistry as a means of creating criteria that will aid in the classification of gold-bearing successions. Ultimately, exploration costs can be lowered by geochemically distinguishing gold-bearing stratigraphic units within an overall regional fine-grained succession.

Lambeck et al. (2008) typecasted the Stubbins, Dead Bullock and Killi Killi Formations using $\mathrm{Zr} / \mathrm{Sc}$ and $\mathrm{Th} / \mathrm{Sc}$ ratios, Cr values, and REE patterns combined with detrital zircons populations, and differentiated between the more goldprospective Dead Bullock Formation from the less gold-prospective Stubbins and Killi Killi Formations. In this paper we build upon the techniques developed by Lambeck et al. (2008) and use $\mathrm{Cr} / \mathrm{Th}$ ratios, Th/Sc ratios, (La/Yb) PAAs $_{\text {and }}$ $\mathrm{Eu} / \mathrm{Eu}^{*}$ values, combined with Sm-Nd isotopic variations, to identify changes in sedimentary source for the Proterozoic Tanami region. These characteristics allow us to typecast the major gold bearing lithologies within the poorly exposed fine-grained siltstones and black mudstones of the Tanami gold province. 


\section{Geological setting and stratigraphy}

The Tanami Region is situated in northwest central Australia (Fig. 1) within the North Australia Craton (Myers et al. 1996). The characteristics, relationships and ages of supracrustal rock units and granites in the Tanami region are described by Crispe et al. (2007) and Cross and Crispe (2007) and only a summary is provided here. Table 1 and Figure 2 provide an overview of the Tanami regional stratigraphy. The oldest rocks in the Tanami region are high-grade Neoarchaean metasedimentary rocks and leucogranites ( 2514 $\pm 3 \mathrm{Ma}$ ) that occur within the Billabong Complex (Page et al. 1995, Fig. 1). Although outcrop of Archean rocks is < $5 \%$ total area in the Tanami Region, Page et al. (1995) used $\mathrm{Sm}-\mathrm{Nd}$ isotope data from granites to suggest that Archean rocks are more extensive at depth.

The sedimentary successions within the Tanami region have been subdivided into five events based on geochemistry and geochronology (Table 1). The oldest known Palaeoproterozoic rocks form the Stubbins Formation in Western Australia. This package, described in detail by Bagas et al. (2008), consists of a 2-3 km thick lower succession of interlayed turbiditic sandstone, siltstone, mudstone, and dolerite sills conformably overlain by an upper $200 \mathrm{~m}$ thick succession of iron-rich siltstone and mudstone, carbonaceous mudstone, chert, pillow basalt and dolerite sills with rare rhyolite and lamprophyre dykes. The relationship between the Stubbins Formation and the remainder of the Tanami region is not clear, as the Stubbins Formation is everywhere fault bounded (Bagas et al. 2008). Two SHRIMP U-Pb zircon dates provide maximum depositional ages of $1870 \pm 6$ and $1864 \pm 3 \mathrm{Ma}$ (Bagas et al. 2008). A quartz-porphyry rhyodacite interpreted to intrude the upper part of the Stubbins Formation yields an igneous crystallisation age of 1864 $\pm 3 \mathrm{Ma}$ and is interpreted as the approximate age of the host succession (Bagas et al. 2008).

The Tanami Group consists of the basal Dead Bullock Formation overlain by the Killi Killi Formation (Fig. 2). The basal Ferdies Member of the Dead Bullock Formation consists of a sandy siltstone fining upwards into graphitic units and banded iron formation of the Callie Member (Lambeck et al. 2008). The Callie Member at Dead Bullock Soak is the largest gold producing region in the Northern Territory.

Correlations among units within the Tanami are largely dependent on detrital zircon age data. The detrital spectra of Dead Bullock and Killi Killi Formations are significantly different. The Dead Bullock Formation contains a main peak at $2500 \mathrm{Ma}$ with subsidiary peaks at 2700 and $3200 \mathrm{Ma}$ (Cross and Crispe 2007). No peaks are present younger than $2200 \mathrm{Ma}$, which contrasts with the overlying Killi Killi Formation which contains a dominant detrital zircon peak at $1860 \mathrm{Ma}$ with minor peaks at $2500 \mathrm{Ma}$ and older (Cross and Crispe 2007).

The youngest zircon component of the Killi Killi Formation provides a maximum depositional age of between 1870 $1860 \mathrm{Ma}$. As reported by Cross and Crispe (2007), however, this unit and the underlying Dead Bullock Formation is geochronologically well constrained by an inferred "tuffaceous unit" in the Dead Bullock Formation with an age of $1838 \pm 6$ Ma. Hence the Killi Killi Formation is interpreted to be deposited at least $20 \mathrm{Ma}$ after the age of its youngest detrital zircon component. The Killi Killi Formation, composed of turbiditic siliciclastic rocks consisting of micaceous sandstone, lithic sandstone interbedded with siltstones and carbonaceous mudstones, also hosts gold but it is less extensively mineralised (Crispe et al. 2007). The Killi Killi Formation (and its time correlative, the Lander Rock beds) occurs extensively across the Tanami and northern Arunta regions (Crispe et al. 2007).

Multiple generations of dolerite sills intrude the Tanami Group and are described in detail by Dean (2001). At Dead Bullock Soak, the Dead Bullock Formation is cross-cut by the locally named Coora Dolerite and End it All Dolerite. The dolerites are up to $200 \mathrm{~m}$ thick, and are affected by the same major deformation and metamorphic events as the Tanami Group (Crispe et al. 2007). Crispe et al. (2007) observed peperitic textures on the lower contact of the Coora Dolerite with Dead Bullock Formation and suggested intrusion of the Coora dolerite into soft sediment.

The Ware Group forms part of a regionally widespread episode of volcanism and clastic sedimentation in the Tennant Creek region (Crispe et al. 2007) and the Pine Creek Orogen (Lally and Worden 2004). The Ware Group is dominated by felsic volcanics and coarse-grained lithic sandstones, with minor siltstone and basalt. It includes the Mount Winnecke Formation (Traves 1955; Blake et al. 1975), Nanny Goat Volcanics (Hendrickx et al. 2000), Wilson Formation and Century Formation (Crispe et al. 2007) (Fig. 2). The relationship with the underlying Tanami Group is not exposed, but Crispe et al. (2007) infer an unconformity based on structural observations. SHRIMP U-Pb dating of the Ware Group provides a maximum deposition age of $1815 \pm 13$ Ma (Claoué-Long et al. 2001).

Regional deformation and granite plutonism at $\sim 1800 \mathrm{Ma}$, the Stafford Event, caused extension and localised sedimentation forming the Mount Charles Formation (Cawood and Korsch 2008). The Mount Charles Formation (Fig. 2) is a succession of fine-to-coarse-grained clastic sedimentary rocks intercalated with basalt interpreted to be restricted to the Tanami mine corridor (Crispe et al. 2007). Within the Tanami mine corridor gold mineralisation was restricted to within the sedimentary and basaltic volcanic rocks (Tunks and Cooke 2007). The Mt Charles Formation consists of 
mafic volcanic rocks that are consistent with the existence of an intra continental rift setting at the time of deposition (Tunks and Cooke 2007). The pillow basalts within the Mt Charles Formation are described by Tunks (1996) as intracontinental tholeiites.

An unconformity between the underlying Dead Bullock Formation and the basal, thinly-bedded lithic sandstone is exposed; however, the top of the Mount Charles Formation is not exposed (Crispe et al. 2007). Cross and Crispe (2007) note that obtaining reliable geochronological data from the Mount Charles Formation is problematic. The lack of regional deformation and metamorphism within the Mount Charles Formation suggests it postdates the $\sim 1830-1810 \mathrm{Ma}$ metamorphic and deformational events in the Tanami Group (Crispe et al. 2007). The Mount Charles Formation is interpreted to have a depositional age of $\sim 1810 \mathrm{Ma}, 100 \mathrm{Ma}$ younger than the $\sim 1910 \mathrm{Ma}$ age based on the youngest detrital zircons (Cross and Crispe 2007).

The Pargee Sandstone is a thick succession of interbedded conglomerate, pebbly sandstone, quartz-rich sandstone and minor siltstone. Based on ${ }^{40} \mathrm{Ar} /{ }^{39} \mathrm{Ar}$ thermo-geochronology and detrital zircon geochronology, sediments forming the Pargee Sandstone may have been sourced from the Arunta Block (Crispe et al. 2007). The Pargee Sandstone has a maximum deposition age of 1768 \pm 14 Ma (Claoué-Long et al. 2001; Cross and Crispe 2007). This unit unconformably overlies cleaved siltstone of the Killi Killi Formation, and is unconformably overlain by the Gardiner Sandstone, the basal unit of the Birrindudu Group (Blake et al. 1975; Blake et al. 1979). As no significant gold prospects are found within the Pargee Sandstone or the overlying Birrindudu Group, they are not included as part of this study.

\section{Sampling and analytical methods}

Drill cores were selected in consultation with Newmont and Tanami Gold mine geologists to cover the full stratigraphic succession and minimise structural complications. The Stubbins, Dead Bullock, Mt Charles and Killi Killi Formations, and Ware Group were sampled from either drill holes or limited outcrop from regions where the regional stratigraphy is known (Crispe et al. 2007). Lambeck et al. (2008) have previously reported composite stratigraphy and lithologic geochemical sections through the Stubbins Formation, Callie deposit, the Cashel and Sunline prospects, and the Dead Cat Rock and Apertawonga outcrop sections. The composite section of the Mount Charles Formation stratigraphy was constructed in a similar fashion to the composite section completed at the Dead Bullock Soak goldfield (Lambeck et al. 2008). Lack of available core limited sampling of the full Mount Charles stratigraphic section, and only $\sim 300 \mathrm{~m}$ of representative core was sampled. The Mount Charles Formation, including significant occurrences of pillow basalts, is estimated to be $\sim 3000 \mathrm{~m}$ thick (Tunks 1996). Diamond drill holes RGD 116, DDH076, CAD053 and HRD003 were used for the Mount Charles Formation composite downhole profile.

Whole-rock and trace element analyses were carried out on 434 samples in three batches. The first batch (62 samples) consisted of split pulp samples crushed in tool steel by Newmont Australia. The second batch (225 hand samples, 50$300 \mathrm{~g}$ ) was prepared in either a tungsten-carbide mill or tool steel mill at Geoscience Australia. The third batch (147 samples) consisted of samples from drill core ground on site to a fine powder (approximately $20 \mathrm{~g}$ ), using a diamond core grinder. Between samples the core grinder was cleaned with compressed air to avoid contamination. The ground powder from the cores was visually inspected and found to contain small chips from the diamond-grinding wheel. To exclude potential contamination, the chemistry of the cutting wheel was determined and elements that were major components of the wheel (W, $\mathrm{Ag}, \mathrm{Cu}, \mathrm{Zn}, \mathrm{Mn}, \mathrm{Ni}, \mathrm{Fe}$ ) were removed from the geochemical database for data analysis and interpretation. In addition, seven outcrop samples, including a sample of felsic volcanics were taken from the Ware Group and were analysed for whole-rock and trace element geochemistry. Three representative samples of whole-rock geochemistry from each of the regional stratigraphic units are given in Table 2. The total dataset for whole-rock major and trace element analysis can be accessed from 'Appendix A, Supplementary data' for the Mt Charles Formation and Ware Group, and in Lambeck et al. (2008) for the Stubbins Formation, Tanami Group and Sunline and Cashel Prospects.

Abundances of major and trace elements were determined at Geoscience Australia, Canberra using XRF and ICP-MS techniques. Major and minor elements ( $\mathrm{Si}, \mathrm{Ti}, \mathrm{Al}, \mathrm{Fe}, \mathrm{Mn}, \mathrm{Mg}, \mathrm{Ca}, \mathrm{Na}, \mathrm{K}, \mathrm{P} \& \mathrm{~S}$ ) were determined by wavelengthdispersive XRF on fused discs using methods similar to those of Norrish and Hutton (1969). Precision for these elements is better than $\pm 1 \%$ of the reported values. Arsenic, $\mathrm{Ba}, \mathrm{Cr}, \mathrm{Cu}, \mathrm{Ni}, \mathrm{Sc}, \mathrm{V}, \mathrm{Zn} \& \mathrm{Zr}$ were determined by pressed pellet on a wavelength-dispersive XRF using methods similar to those described by Norrish and Chappell (1977). Selected trace elements (Cs, Ga, Nb, Pb, Rb, Sb, Sn, Sr, Ta, Th, U, Y) and the rare earth elements were analysed at Geoscience Australia by ICP-MS (Agilent 7500ce with reaction cell) using methods similar to those of Eggins et al. (1997), but on solutions obtained by dissolution in distilled $\mathrm{HF}$ and $\mathrm{HNO}_{3}$ acid of the fused glass discs (Pyke 2000). Precisions are 5\% and 10\% at low levels. Agreement between XRF and ICP-MS (Ba, Nb, Pb, Rb, Sr, Y, $\mathrm{Zr}$ ) are within $10 \%$. 
Based on the existing and new geochemical data, a suite of 28 sedimentary samples, eight basalts and dolerites and a felsic volcanic rock were analysed for Sm-Nd isotopic composition as part of this study. Isotope analyses were determined by isotope dilution in two batches. Fifteen samples were completed at Adelaide University using techniques detailed in Wade et al. (2005). Samples were evaporated in $\mathrm{HF}-\mathrm{HNO}_{3}$ overnight, digested in hot $\mathrm{HF}-\mathrm{HNO}_{3}$ in sealed Teflon vials for 5 days, then evaporated to dryness in $\mathrm{HF}-\mathrm{HNO}_{3}$. Samples were subsequently evaporated in $6 \mathrm{M} \mathrm{HCl}$ and then bombed with $6 \mathrm{M} \mathrm{HCl}$ overnight. $\mathrm{Nd}$ and $\mathrm{Sm}$ concentrations were calculated by isotope dilution, with $\mathrm{Nd}$ isotope ratios measured by thermal ionization mass spectrometry on a Finnigan MAT 262 mass spectrometer and Sm isotope ratios measured on a Finnigan MAT 261 mass spectrometer. The running average for the La Jolla standard is $0.511289 \pm 8(\mathrm{n}=134)$. Twenty-one samples were analysed at La Trobe University using techniques detailed in Wade et al. (2005) and in Waight et al. (1998; 2000).

\section{Geochemical results}

To enable a direct comparison, all analyses were recalculated to $100 \%$ volatile-free, and all samples containing greater than $5 \% \mathrm{CaO}$ or greater than $5 \%$ loss of ignition were excluded from further consideration (Roser and Korsch 1986). This minimized any possible effect of disturbance by alteration and allows drill cores to be compared regionally.

\section{Major elements}

Ternary diagrams of major element plots using Nesbitt and Young $(1984 ; 1989)$ display a separation in the data (Figs. 3a \& 3b). The Dead Bullock and Mount Charles Formations appear to be more enriched in $\mathrm{Al}_{2} \mathrm{O}_{3}$ compared to the Stubbins and Killi Killi Formation and Ware Group. The ternary diagram of $\mathrm{Al}_{2} \mathrm{O}-\left(\mathrm{CaO}+\mathrm{Na} 2 \mathrm{O}+\mathrm{K}_{2} \mathrm{O}\right)-\left(\mathrm{FeO}^{\mathrm{T}}+\mathrm{MgO}\right)$ (Nesbitt and Young 1989; Bierlein et al. 1998) is modified here to show two separate sedimentary provenances, a felsic provenance and a mafic provenance (Fig. 3b). The Dead Bullock Formation samples contain higher $\mathrm{FeO}^{\mathrm{T}}+\mathrm{MgO}$ than the Killi Killi samples which are more dominated by muscovite and K-feldspar. Samples from the Stubbins Formation, Ware Group and Mount Charles Formation that were prepared under different laboratory conditions and contain potential Fe contamination as detailed in the methods and the data were excluded in this plot.

Effects of alteration associated with hydrothermal and regional metamorphic processes must be taken into account when defining changes in regional sedimentary provenance in the Tanami region (Williams 2007). Bagas et al. (2008) discussed hypogene alternation in the Tanami region due to either greenschist facies metamorphism or associated mineralising events and showed that the more mobile elements have been affected (e.g. $\mathrm{CaO}, \mathrm{Na}_{2} \mathrm{O}$ and $\mathrm{K}_{2} \mathrm{O}$ ). Therefore to define changes in regional sedimentary provenance using sedimentary geochemistry selected immobile elements need to be used.

\section{Regional chemostratigraphy}

Variations in sedimentary provenance can be used to understand geological evolution of regions (e.g. Prame and Pohl 1994; Slack and Stevens 1994; Dabard et al. 1996; Garzione et al. 1997; Roser et al. 2002). Condie and Wronkiewicz (1990) concluded that the $\mathrm{Cr} / \mathrm{Th}$ ratio in pelites can provide an important geochemical index of early Precambrian crustal evolution and can be used to monitor changes in source composition with strong correlations to $\mathrm{Th} / \mathrm{Sc}, \mathrm{Sc} / \mathrm{Th}$ and $\mathrm{La} / \mathrm{Sc}$ ratios. The use of rare earth elements (REE) as provenance indicators requires assumptions to be met; (1) they are not significantly modified by metamorphism and diagenesis (Michard 1989; Bau 1991), and (2) that the REE were quantitatively transported in the detrital component (McLennan and Taylor 1982; Crichton and Condie 1993; Ugidos et al. 1997; Robinson et al. 2001).

Sedimentary geochemistry, detrital U-Pb ages and $\mathrm{Nd}$ isotopic signatures provide independent tools to help discriminate tectonic setting and sedimentary provenance (e.g. McLennan et al. 1993; McLennan et al. 1995; Yamashita et al. 2000; Goodge et al. 2002; Lahtinen et al. 2002; Tran et al. 2003; González-Álvarez et al. 2006; Payne et al. 2006; Barovich and Hand 2008; Tran et al. 2008). U-Pb geochronology of zircon-bearing sources provides an age spectrum and maximum depositional age of the sediment. Limitations of detrital zircon geochronology discussed by Barovich and Hand (2008) include: (1) loss of small zircons in separation; (2) lack of contribution from fine-grained sources; and (3) lack of contribution from less felsic sources. Once weathering and sorting processes are accounted for (e.g. Cullers and Podkovyrov 2000; López et al. 2005), Sm-Nd studies combined with REE and detrital U-Pb studies, record information on the average crustal residence time of sediment from all contributing protoliths and distinguish between mantlederived igneous and evolved crustal evolved sources. Sm-Nd data however, are unable to separate individual protolith ages (McLennan et al. 1993). Through a combination of sedimentary geochemistry, detrital zircon U-Pb, and Sm-Nd isotope studies, a relatively clear picture of the crustal segments from which the sedimentary package was sourced can be created. Detrital zircon SHRIMP U-Pb ages (Cross and Crispe 2007; Bagas et al. 2008) provide lower and upper age constraints on the regional stratigraphic succession of the Tanami Basin. 
The geochemical and REE data for each of the regional stratigraphic units are presented in Table 1 and Figures 4 to 7 . The Callie composite section from Lambeck et al. (2008) and a new composite section for the Mt Charles Formations are presented in Figure 4. Downhole composite plots of $\mathrm{Th} / \mathrm{Sc}$ and $\mathrm{Cr} / \mathrm{Th}$ ratios at Dead Bullock Soak and in the Mount Charles Formation show the Dead Bullock Formation has low $\mathrm{Th} / \mathrm{Sc}$ and high $\mathrm{Cr} / \mathrm{Th}$ ratios compared to the Killi Killi Formation. The composite downhole log of the Mount Charles Formation is highlighted by high $\mathrm{Cr} / \mathrm{Th}$ ratios and low $\mathrm{Th} / \mathrm{Sc}$ ratios. Data from the $\mathrm{Cr} / \mathrm{Th}-\mathrm{Th} / \mathrm{Sc}$ plot distinguish the Dead Bullock Formation and Mount Charles Formations from the remainder of the regional stratigraphy by having $\mathrm{Cr} / \mathrm{Th}$ values $>10$ and $\mathrm{Th} / \mathrm{Sc}$ values $<1$ (Fig. 5). The Dead Bullock and Mount Charles Formations are light REE depleted, relative to PAAS and the remainder of the regional stratigraphic units have flat REE patterns (Fig. 6), apart from the Cashel and Sunline Prospects which are light REE depleted (Fig. 7).

\section{Stubbins Formation}

Twenty-nine geochemical analyses of drill core samples were analysed from the Stubbins Formation which have high $\mathrm{Th} / \mathrm{Sc}$ ratios (3-6) and low (<100 ppm) Cr abundances and flat REE patterns relative to PAAS (Lambeck et al. 2008). The mixed coarse-to-fine-grained sedimentary rocks of the Stubbins Formation have average $\mathrm{Cr} / \mathrm{Th}$ and $\mathrm{Th} / \mathrm{Sc}$ ratios of 3.1 and 2.3 respectively (Figs. 4 and 5). The REE patterns relative to PAAS are flat and almost identical to PAAS with an average $(\mathrm{La} / \mathrm{Yb})_{\text {PAAS }}$ value of 1.5 ; the average Eu anomaly (Fig. 6) is $0.8(\mathrm{Eu} / \mathrm{Eu} *=(\mathrm{Eu} / 1.1) /((\mathrm{Sm} / 5.6+\mathrm{Gd} / 4.7) / 2)$. Three initial $\varepsilon_{\mathrm{Nd}}$ values (calculated at $1860 \mathrm{Ma}$ ) of sedimentary rocks from the Stubbins Formation range between -6.3 and -5.7. Two $\varepsilon_{\mathrm{Nd}}$ values were calculated for the Stubbins Basalt at 1.4 and 0.6 respectively (Table 3 and Figure 8).

\section{Dead Bullock Formation}

One hundred and two geochemical analyses were obtained from the Dead Bullock Formation, as defined by Lambeck et al. (2008), and have low Th/Sc ratios (<2), high (>100 ppm) Cr abundances, and LREE depleted PAAS normalised REE patterns. The mixed coarse-to-fine grained sedimentary rocks of the Dead Bullock Formation have average $\mathrm{Cr} / \mathrm{Th}$ and $\mathrm{Th} / \mathrm{Sc}$ ratios of 63.5 and 0.2 respectively (Figs. 4 and 5). The REE patterns are light REE depleted with an average $(\mathrm{La} / \mathrm{Yb})_{\text {PAAS }}$ value of 0.5 , the average Eu anomaly is 1.3 (Fig. 6).

One initial $\varepsilon N d$ (calculated at $1860 \mathrm{Ma}$ ) of sedimentary rock from the Ferdies Member at the Callie Mine is -6.0 (Table 3). Samples assigned to the basal Ferdies Member of the Dead Bullock Formation from the Groundrush area by Crispe et al. (2007), have initial $\varepsilon_{\mathrm{Nd}}$ values of -10.9 and -9.7 at $1860 \mathrm{Ma}$ (Fig. 8, Table 3). Initial $\varepsilon_{\mathrm{Nd}}$ values at $1838 \mathrm{Ma}$ for the Callie Member, Dead Bullock Formation, vary from -6.9 to -6.4. Initial values for the Coora Dolerite, one from about $5 \mathrm{~m}$ from the basal contact and one from the middle of the $\sim 200 \mathrm{~m}$ thick dolerite are +1.6 and +1.1 respectively at 1838 Ma.

\section{Killi Killi Formation}

Twenty-nine geochemical analyses of drill core samples were completed for the Killi Killi Formation. These have high $\mathrm{Th} / \mathrm{Sc}$ ratios (3-6), low (<100 ppm) Cr abundances, and flat REE patterns relative to PAAS (Lambeck et al. 2008). The coarse-to-fine-grained sedimentary rocks of the Killi Killi Formation have average $\mathrm{Cr} / \mathrm{Th}$ and $\mathrm{Th} / \mathrm{Sc}$ ratios of 2.7 and 2.1 respectively (Figs. 4 and 5). The REE patterns are flat and almost identical to PAAS with an average (La/Yb) PAAS value of 1.3; the average Eu anomaly is 0.9 (Fig. 6). Initial $\varepsilon N d(1840 \mathrm{Ma})$ values from the Killi Killi Formation, range from -6.3 to +3.1 (Fig. 8, Table 3 ).

\section{Ware Group}

Seven outcrop samples were analysed from the Ware Group and have high Th/Sc ratios (3-4), low ( $<100 \mathrm{ppm}) \mathrm{Cr}$ abundances, and flat REE patterns relative to PAAS. They include six coarse-to-fine-grained sedimentary samples and one felsic volcanic (analysed for $\mathrm{Nd}$ isotopes). The fine-grained sandstone samples have an average $\mathrm{Cr} / \mathrm{Th}$ and $\mathrm{Th} / \mathrm{Sc}$ ratios of 1.9 and 2.9 respectively (Figs. 4 and 5). The REE patterns are flat and almost identical to PAAS with an average $(\mathrm{La} / \mathrm{Yb})_{\text {PAAS }}$ value of 1.1, and the average Eu anomaly is 0.9 (Fig. 6). Two initial $\varepsilon_{\mathrm{Nd}(1820 \mathrm{Ma})}$ values from the Ware Group are -2.4 and -2.7, The felsic Nanny Goat Volcanics have an $\varepsilon_{\mathrm{Nd}(1820 \mathrm{Ma})}$ value of -10.3 (Fig. 8, Table 3).

\section{Mount Charles Formation}

Fifty-seven geochemical analyses of drill core samples were completed for the Mount Charles Formation. These have low $\mathrm{Th} / \mathrm{Sc}$ ratios $(<2)$ and high $(>100 \mathrm{ppm}) \mathrm{Cr}$ abundances. The poorly-sorted coarse-to-fine-grained sedimentary rocks have average $\mathrm{Cr} / \mathrm{Th}$ and $\mathrm{Th} / \mathrm{Sc}$ ratios of 22.2 and 0.2 respectively (Figs. 4 and 5). The REE patterns are light REE depleted relative to PAAS with an average $(\mathrm{La} / \mathrm{Yb})_{\text {PAAS }}$ value of 0.5 , and the average Eu anomaly is 1.4 (Fig. 6$)$. $\varepsilon_{\mathrm{Nd}(1810}$ Ma) values range from -7.2 to 1.6 which suggest there is a large range of crustal residence ages in the source materials for the sedimentary rocks. Three $\varepsilon_{\mathrm{Nd}(1810 \mathrm{Ma})}$ values from basalts within the Mount Charles Formation are $-2.3,-2.1$ and +6.0 . 
The fine-grained sedimentary rocks of the Cashel and Sunline Prospect sampled by Lambeck et al. (2008) have average $\mathrm{Cr} / \mathrm{Th}$ ratios of 45.8 and 238 respectively, low $\mathrm{Th} / \mathrm{Sc}$ and $(\mathrm{La} / \mathrm{Yb})_{\text {PAAS }}$ values and Eu anomalies of $\sim 0.9$. Three samples from the Cashel and Sunline Prospect have $\varepsilon_{\mathrm{Nd}(1810 \mathrm{Ma})}$ values ranging from -0.2 to +0.6 .

\section{Discussion}

Groves (1993) suggested that gold deposits in the Tanami region may illustrate the continuum model of lode-gold deposition which was confirmed by Mernagh and Wygralak (2007) who illustrated ore deposition occurring at a range of depths from 1.5 to $11 \mathrm{~km}$. While the Tanami region contains a range in mechanisms of lode-gold deposition, Huston et al. (2007) documented that many of these Tanami lode-gold deposits are hosted by reactive rock units such as carbonaceous siltstone and iron formation. The lode-gold deposits hosted within the Dead Bullock and Mount Charles Formations formed during times of regional extension associated with voluminous mafic and felsic magmatism (Crispe et al. 2007; Huston et al. 2007).

Condie (1997) suggested that mixing of sediments derived from Archean and Palaeoproterozoic sources, as documented in Lambeck et al. (2008), could occur in basins adjacent to active continental margins (i.e. back-arc to foreland basin). The tectonic setting and timing of regional extension has been documented by Bagas et al. (2008) who suggested that sedimentary and basalt geochemistry of the Tanami region forms a back-arc basin. Similarly the Mount Charles Formation was deposited during a period of regional extension, (Stafford Event: Cawood and Korsch 2008), in which turbiditic sedimentary rock and basalt were deposited in the post-rift basin.

The fine-grained facies of the Dead Bullock Formation were interpreted by Lambeck et al. (2008) to have been deposited in a deep-water environment to form $\sim 600 \mathrm{~m}$ of well-bedded carbonaceous rocks. These acted as reductants to oxidised metalliferous fluid that travelled along D5 shears and deposited gold when thick carbonaceous horizons were encountered (Huston et al., 2007; Williams, 2007). Gold in the Mount Charles Formation is hosted mainly within basalt but also present in the base of carbonaceous mudstone units above basalt flows (Huston et al. 2007).

Being able to geochemically discriminate these gold-prospective carbonaceous units within the predominantly finegrained regional stratigraphy will ultimately help to reduce gold exploration risk. Traditionally, coarse-grained sedimentary rocks in the Tanami region have been mapped as Killi Killi Formation and fine-grained sedimentary rocks and black mudstones have been mapped as Dead Bullock Formation or Mount Charles Formation (Smith et al. 1998). As shown by Lambeck et al. (2008), this criterion is not entirely reliable, and thick black mudstones can be found within the Killi Killi Formation. When gold tonnage (sum of gold resources, production and stockpiles) is calculated for the regional stratigraphy (Table 1) the main gold bearing units of the Dead Bullock and Mt Charles Formations are highlighted containing in excess of 320 tonnes of gold, representing $90 \%$ of the known gold in the Tanami region.

\section{Suggested evolution of the Tanami geochemical variations}

In this section the model of the early Tanami evolution discussed by Cross and Crispe (2007) is assessed using the regional sedimentary geochemical data (Fig. 9). Five geochemical events are defined in this paper and discussed in geochronological order starting at the basal geochemical event.

\section{Stubbins Formation; Event 1}

The stratigraphic relationship of the Stubbins Formation, which is only known in the western Tanami region, is enigmatic within the regional stratigraphy. Based on the $\sim 1864$ Ma depositional age (Bagas et al. 2008), the Stubbins Formation is stratigraphically below the $\sim 1838$ Ma interpreted "tuffaceous sandstone" of the Dead Bullock Formation in the northern Tanami region. It should be noted however, that both the Stubbins and Killi Killi Formations contain detrital zircon populations with ages between $1860 \mathrm{Ma}$ and $1870 \mathrm{Ma}$, the Dead Bullock Formation only contains detrital zircons older than 2500 Ma (Cross and Crispe 2007; Bagas et al. 2008).

Samples from the Stubbins Formation have a REE patterns that are almost identical to that of PAAS (Fig. 6). Small standard deviations for $\mathrm{La} / \mathrm{Yb}_{\mathrm{PAAS}}$ indicate a very homogeneous source. $\mathrm{Th} / \mathrm{Sc}$ and $\mathrm{Cr} / \mathrm{Th}$ ratios of $\sim 2.3$ and $\sim 3.1$ respectively suggest that the Stubbins Formation is derived from a felsic source (Taylor and McLennan 1985; Condie and Wronkiewicz 1990; McLennan et al. 1990; Lahtinen 2000; Lahtinen et al. 2002). The source must have been strongly evolved, as reflected by the average $\varepsilon_{\mathrm{Nd}(1860 \mathrm{Ma})}$ value of $\sim-5$. Due to the local occurrence of the coarse-to-finegrained siliciclastic rocks, our data support the interpretation of Lambeck et al. (2008) and suggest that the Stubbins Formation was deposited in a restricted basin with a chemically differentiated source (Fig. 9). Based on whole-rock geochemistry, Bagas et al. (2008) proposed that the basalts in the Stubbins Formation were formed in an extensional setting. 
Dead Bullock Formation; Event 2

Both the Ferdies and Callie Members of the Dead Bullock Formation are interpreted to have been derived from Archean mafic and felsic rocks on the basis of $\mathrm{Th} / \mathrm{Sc}, \mathrm{Zr} / \mathrm{Sc}, \mathrm{Cr}$ and $\mathrm{REE}$ values (Lambeck et al. 2008). The basal Ferdies Member, as represented by samples from the Groundrush area, was derived from an evolved source with $\varepsilon_{\mathrm{Nd}(1860 \mathrm{Ma})} \sim$ -10 , and is unique in the Tanami region (Fig. 8). The overlying Callie Member also records an evolved source $\varepsilon_{\mathrm{Nd}}(1840)$ $\mathrm{Ma} \sim-6$. Page et al. (1995) used U-Pb ages combined with Nd-isotope model ages and whole-rock geochemistry to infer the existence of largely-concealed late Archean crust in this region. The evolved $\varepsilon_{\mathrm{Nd}}$ values from the Ferdies and Callie Members (Figure 8 and Table 3) support the interpretation of Page et al. (1995) that the source of the sedimentary rocks was dominantly Archean granitic crust. This is consistent with the presence of 2500, 2700 and 3200 Ma zircons in the Dead Bullock Formation (Cross and Crispe 2007).

The source of the sedimentary rocks in the Dead Bullock Formation is not known but possibilities include Archean provinces in the West Australia Craton or Archean rocks of the Tanami Province. Goleby et al. (2008) suggests that deposition of the Dead Bullock Formation may have occurred during regional extension (Fig. 9). The sandy siltstone and black mudstones were probably deposited in a deep-water setting and were derived from a remote Archean mafic and felsic source (Lambeck et al. 2008) (Fig. 9). The depositional age of the Ferdies Member is poorly constrained between 2110 - $1840 \mathrm{Ma}$ (Cross and Crispe 2007).

\section{Killi Killi Formation; Event 3}

Lambeck et al. (2008) concluded that the contact between the Dead Bullock and overlying Killi Killi Formations is conformable but a change in sedimentary source is recorded. The Killi Killi Formation (Th/Sc >2.1, Table 1) was derived from sources with variable crustal residence ages as shown by the wide range of $\varepsilon_{\mathrm{Nd}(1840 \mathrm{Ma})}$ values; $\sim-6$ to +3 (Table 3). Detrital U-Pb zircon data (Cross and Crispe 2007) place maximum depositional ages for the Killi Killi Formation at $\sim 1860 \mathrm{Ma}$. Lambeck et al. (2008) suggested that black mudstones of Apertawonga are part of the Killi Killi Formation, based on high $\mathrm{Th} / \mathrm{Sc}$ ratios. The most juvenile $\varepsilon_{\mathrm{Nd}}$ values of the fine-grained turbidites are +1.0 and +3.3 at Apertawonga. These sedimentary rocks are attributed to a relatively local juvenile source not previously recorded in the Tanami region (Table 3, Fig. 9). The varied $\varepsilon_{\mathrm{Nd}}$ values are interpreted to indicate deposition in localised basins. This may be due to development of separate rift shoulders with poor mixing among canyon slope systems. Sedimentation of the Killi Killi facies was terminated by regional deformation at about 1840-1825 Ma .

\section{Ware Group, deposition; Event 4}

Unconformably overlying the Tanami Group sedimentary rocks is the regionally extensive Ware Group, deposited during a time of regional extension at $1825-1810 \mathrm{Ma}$ (Cross and Crispe 2007, Fig. 9). The highly negative initial $\varepsilon_{\mathrm{Nd}}$ value from the felsic Nanny Goat Volcanics (-10.3) suggests an evolved source derived from melting of Archean crust. Figures 5 and 6 suggest relative enrichment of LREE and Th, and lower Cr values relative to the underlying Dead Bullock and overlying Mount Charles Formations which imply a more felsic source component. The shallow water/fluvial sedimentation was halted by uplift resulting from regional deformation and granite plutonism (Crispe et al. 2007).

\section{Mount Charles Formation; Event 5}

The Mount Charles Formation was deposited at a time of localised extension during the regional Stafford Event (Claoué-Long and Hoatson 2005; Cawood and Korsch 2008) (Fig. 9). The fine-to-coarse clastic sedimentary rocks have a low $(\mathrm{La} / \mathrm{Yb})_{\text {PAAS }}$ ratio of 0.5 interpreted to reflect a relatively mafic source.

The mafic Mount Charles Formation is distinguished from the mafic Dead Bullock Formation by Cr/Th ratios (Fig. 4). Initial $\varepsilon_{\mathrm{Nd}}$ isotopic values for both units can also help differentiate between them (Fig. 8). The Dead Bullock Formation has $\varepsilon_{\mathrm{Nd}}(1860 \mathrm{Ma})$ of $\sim-6$ whereas the Mount Charles Formation yields a range of $\varepsilon_{\mathrm{Nd}}$ values from $\sim-7$ to +1.6 at 1810 Ma. The $\varepsilon_{\mathrm{Nd}}(1838 \mathrm{Ma})$ values from the dolerite units within the Dead Bullock Formation are $\sim+1$ compared to $\varepsilon_{\mathrm{Nd}}$ values from the Mount Charles Basalts which range from -2.1 and +6.0. Nd isotope data from the Dead Bullock Formation support derivation from a long-lived mantle source. $\varepsilon_{\mathrm{Nd}}$ values from sedimentary rocks of the Mount Charles Formation range from -7.2 to +1.6 at $1810 \mathrm{Ma}$ and may indicate a mixed source of Archean and Proterozoic maficfelsic volcanic rocks.

\section{Implications for gold exploration}

The gold-prospective Dead Bullock and Mount Charles Formations cannot be distinguished in hand specimen from other regional stratigraphic units, but can be identified using whole-rock, trace element and Nd isotopic values. Figure 5 shows that the Dead Bullock and Mount Charles Formations have lower $\mathrm{Th} / \mathrm{Sc}$ and higher $\mathrm{Cr} / \mathrm{Th}$ ratios than the Stubbins and Killi Killi Formations, and Ware Group, which we interpret to indicate a more mafic source. Although 
gold is known in most units in the Tanami region, the largest deposits are hosted by the Dead Bullock and Mount Charles Formations, probably because these units were more effective as chemical trap rocks (Huston et al. 2007; Bagas et al. 2008). To illustrate the relationship between chemostratigraphy and gold mineralisation, the $\mathrm{Cr} / \mathrm{Th}, \mathrm{Th} / \mathrm{Sc}$, $(\mathrm{La} / \mathrm{Yb})_{\text {PAAS }}$ and $\mathrm{Eu} / \mathrm{Eu}^{*}$ values for each regional stratigraphic unit are plotted relative to gold tonnage (Figures 10a-d). The Sm-Nd data from the Tanami regional stratigraphy are shown in Table 3. The data presented above suggest that geochemical parameters can be used to identify the more fertile Dead Bullock and Mount Charles Formations. These diagrams show that, in the Tanami region, geochemical signatures can be used to discriminate more prospective hosts, which display $\mathrm{Cr} / \mathrm{Th}>10, \mathrm{Th} / \mathrm{Sc}<1,(\mathrm{La} / \mathrm{Yb})_{\text {PAAS }}<1$, and positive or negative Eu anomalies. The "mafic" Dead Bullock and Mount Charles Formations can be distinguished by $\mathrm{Cr} / \mathrm{Th}$, and initial $\varepsilon_{\mathrm{Nd}}$ values.

The Sunline and Cashel Prospects contain high Cr values, (>110 ppm), low Th/Sc ratios (<1) (Lambeck et al. 2008) and are LREE depleted (Fig. 7). The whole-rock and trace element data from the Cashel and Sunline prospects, combined with initial $\varepsilon_{\mathrm{Nd}}$ isotopic values, suggest that the prospects are hosted by the Mount Charles Formation (Figs. 7 and 9 , Table 3). These results suggest new prospects for further exploration within possible Mt Charles stratigraphy. Whereas potential ore-bearing stratigraphy has been identified, detailed work is still required to find prospective chemical traps (cf. Huston et al. 2007; Williams 2007). At this stage, Dead Bullock Formation has only been identified at Callie and possibly at Titania (Lambeck et al. 2008).

Linking the geochemical and geochronological methodology in this way permits development of an enhanced paleogeographic model and provides a new regional exploration strategy for the Tanami region. The geochemical approach discussed in this paper can be applied to other Proterozoic terrains; though the individual diagnostic geochemical features, (i.e. specific REE patterns, $(\mathrm{La} / \mathrm{Yb})_{\mathrm{PAAS}}$ values, $\mathrm{Th} / \mathrm{Sc}$ values, $\mathrm{Cr} / \mathrm{Th}$ values, and $\left.\varepsilon_{\mathrm{Nd}}\right)$ discussed in this paper are, clearly terrain-specific.

\section{Conclusions}

Gold-prospective stratigraphy in the Tanami region can be identified in deep-water turbidite facies, within which rocks derived from sediments deposited under anoxic conditions form a reductant for the oxidised gold-bearing fluid. The gold-prospective black carbonaceous stratigraphy can be geochemically identified from other non-gold-bearing stratigraphy by $\mathrm{Cr} / \mathrm{Th}$ ratios combined with $\mathrm{Th} / \mathrm{Sc}$ values, $\mathrm{La} / \mathrm{Yb}$ PAAs ratios and the Eu anomaly. The $\varepsilon_{\mathrm{Nd}}$ values may also provide important geochemical indicators of basin evolution and deep-water facies in the Tanami region.

Our results from the Tanami region indicate that a series of events occurred over more than 50 Ma. The data suggest that these were a series of separate events involving extension and contraction. Of the sedimentary units formed during these events, the Dead Bullock and the Mount Charles Formations contain the largest gold resource and are geochemically characterised by:

(1) high $\mathrm{Cr} / \mathrm{Th}$ values $(>10)$;

(2) low $\mathrm{Th} / \mathrm{Sc}$ values $(<1)$;

(3) low $(\mathrm{La} / \mathrm{Yb})_{\text {PAAS }}(<1)$;

(4) Eu anomaly + or -

(5) $\varepsilon_{\mathrm{Nd}}$ values that assist in defining stratigraphic position.

The geochemical techniques described may assist exploration for lode-gold deposits in other basins. Identifying the deepest parts of sedimentary basins and discriminating the prospective stratigraphy using the sort of geochemical proxies discussed in this paper could reduce exploration risk. Geochemically discriminating deep-water facies such as thick carbonaceous horizons within the poorly-exposed Tanami region can help in discrimination of prospective packages. The Sunline and Cashel Prospects contain geochemical evidence of a mafic provenance similar to that of the highly prospective Mount Charles Formation.

\section{Acknowledgements}

This work could not have been carried out without support and assistance from Newmont Australia and Tanami Gold. Many thanks are given to Chris Campbell from Newmont for his continued support during this project and to Cathy Crowther from Newmont for her help and enthusiasm in sampling the Mount Charles Formation. We are grateful to Tim Smith, Jim Anderson and Luc English from Tanami Gold for help in gathering samples. The Northern Territory Geological Survey also provided logistical support and Andrew Crispe and Leon Vandenberg provided many useful discussions. At Geoscience Australia, much help was received; many thanks to David Champion, Nick Williams and Natalie Kositcin for their discussions, advice and reviews. Many thanks to John Pyke, Bill Pappas, Liz Webber and Mike Smith for sample preparation and geochemical analyses. We are grateful to Martin Hand from Adelaide University and Russell Korsch from Geoscience Australia who critically read earlier versions of the manuscript and two 
anonymous reviewers who greatly helped in improving the manuscript. Many thanks to David Bruce at Adelaide University and Graeme Luther and John Webb from La Trobe University for Sm-Nd analysis. 


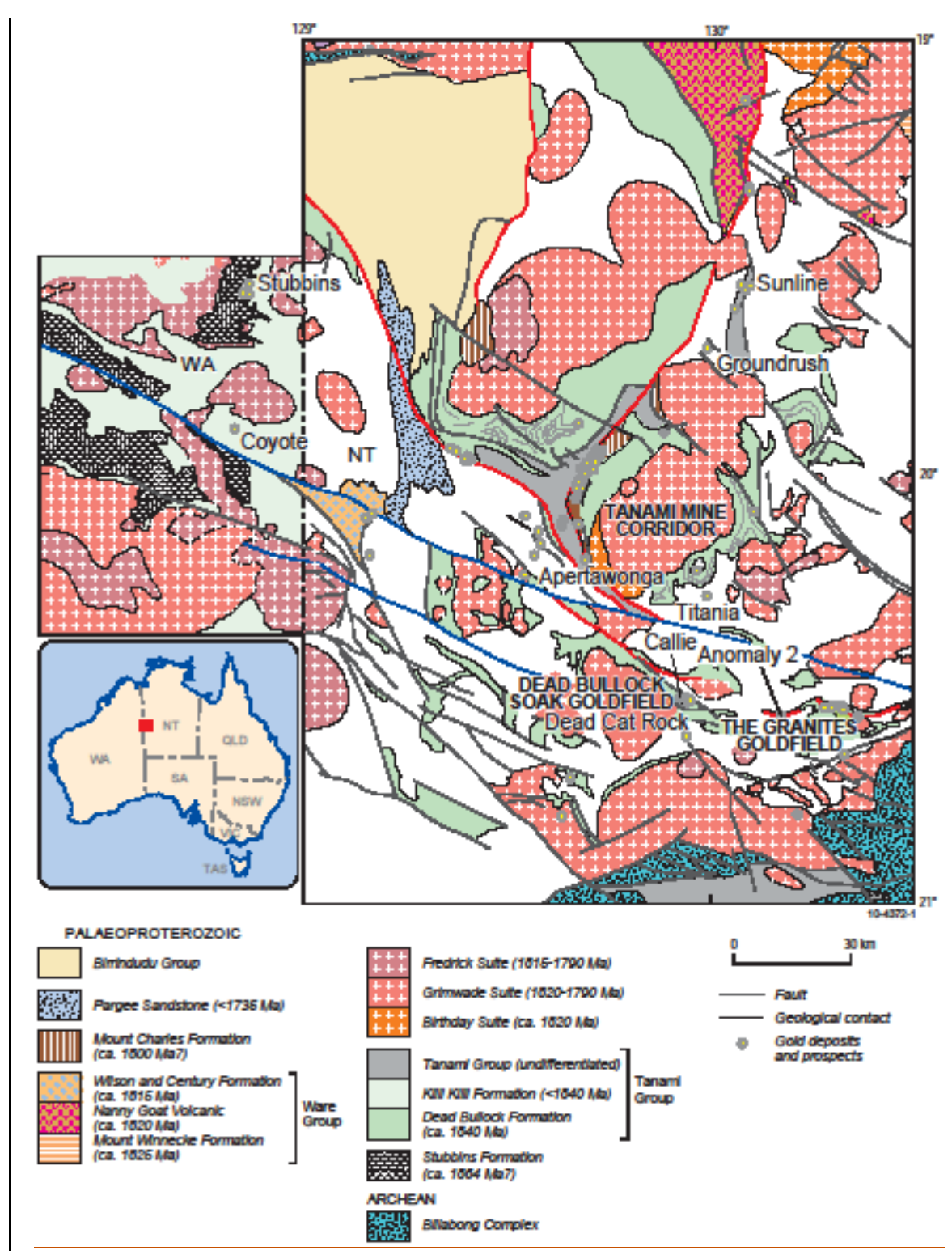

Fig. 1. Solid geology of the Proterozoic units in the Tanami region (Huston et al. 2007). The Cashel Prospect is $39 \mathrm{~km}$ east of Anomaly 2 within mapped undifferentiated Tanami Group. 


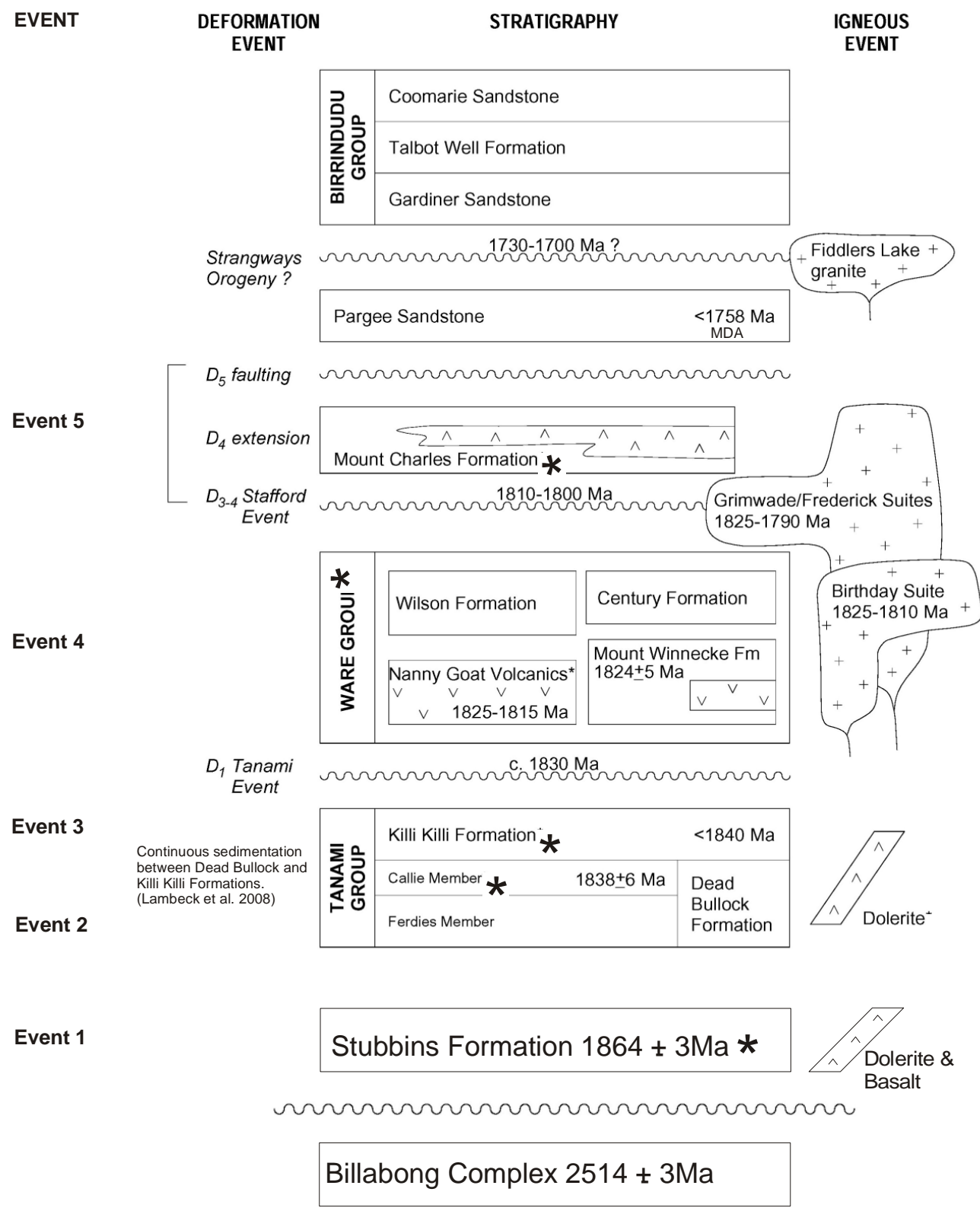

Fig. 2. Regional stratigraphy of the Tanami region from Crispe et al. (2007). Asterisks indicate significant gold mineralisation. Geochronology of the Tanami region is detailed in Table 1. 


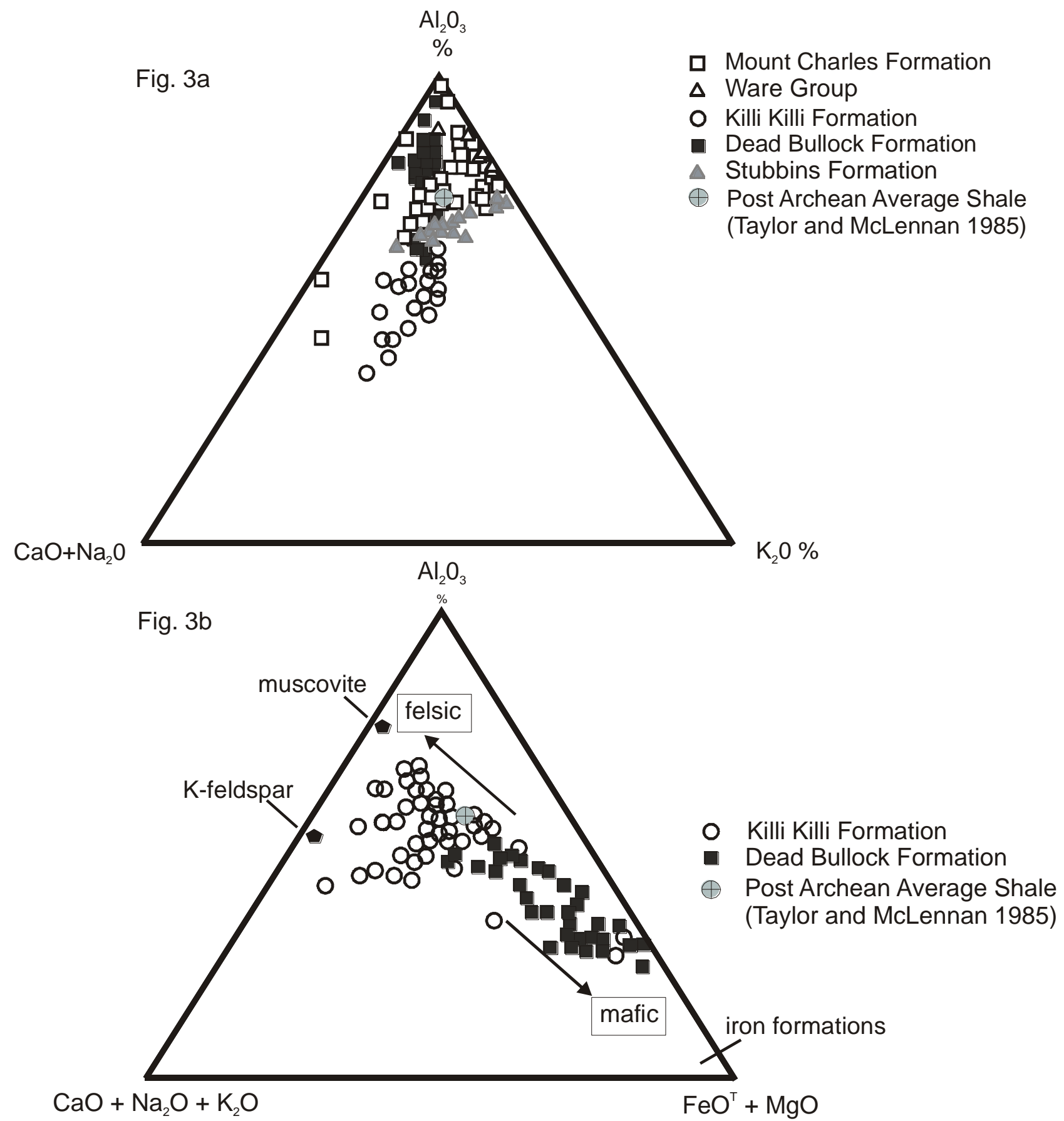

Fig. 3a. Triangular diagram of molecular $\mathrm{Al}_{2} \mathrm{O}_{3}-\mathrm{CaO}+\mathrm{Na}_{2} \mathrm{O}-\mathrm{K}_{2} \mathrm{O}$ (cf. Nesbitt and Young 1984). The gold-bearing Dead Bullock and Mount Charles Formations have high $\mathrm{Al}_{2} \mathrm{O}_{3}$ and can be distinguished from the less aluminous Stubbins and Killi Formations and Ware Group sedimentary rocks.

Fig. 3b. Triangular diagram of molecular $\mathrm{Al}_{2} \mathrm{O}_{3}-\left(\mathrm{CaO}+\mathrm{Na}_{2} \mathrm{O}+\mathrm{K}_{2} \mathrm{O}\right)-\left(\mathrm{FeO}^{\mathrm{T}}+\mathrm{MgO}\right)(\mathrm{Nesbitt}$ and Young 1989) showing compositional variations between the Dead Bullock and Killi Killi Formations. The Stubbins and Mount Charles Formations are not shown in this plot due to contamination as described in methods. 
a)

Dead Bullock Soak Stratigraphy
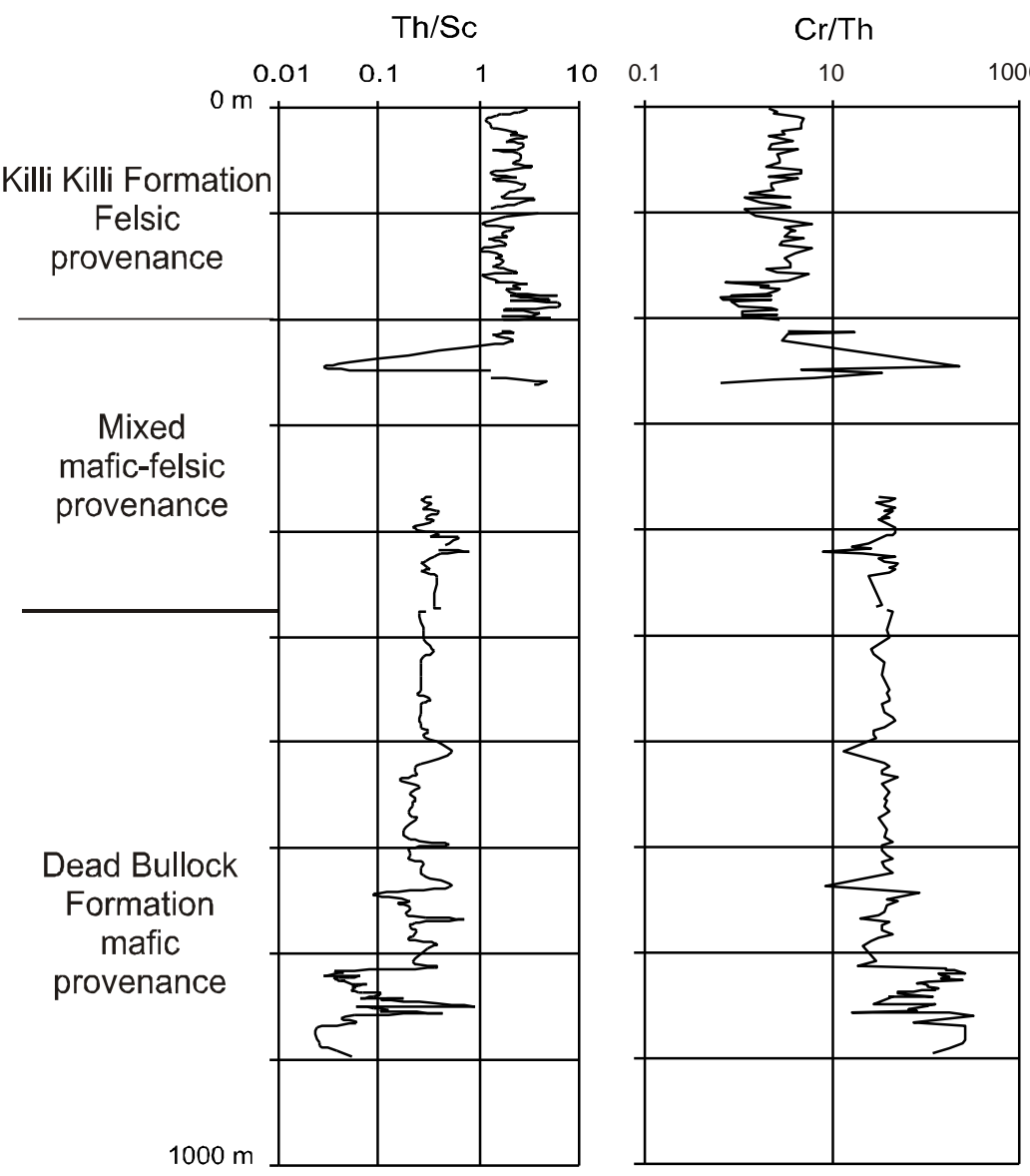

Drill hole

1000

b)

Th/Sc

$\mathrm{Cr} / \mathrm{Th}$

Drill hole

$(\mathrm{n}=76)$

DBD 440

$(\mathrm{n}=127)$

DBD 419
$(n=16)$

DBD 431

$(n=36)$

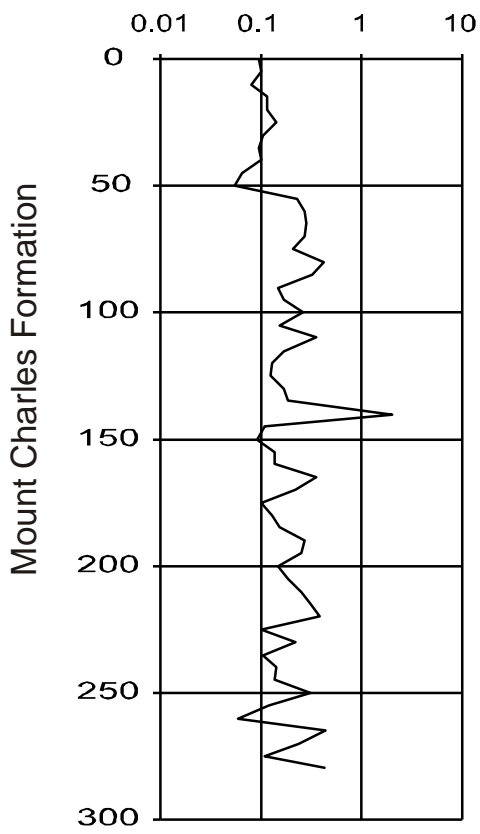

$\begin{array}{lll}0.1 & 10 & 1000\end{array}$

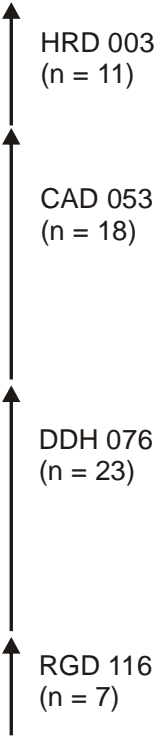

Fig. 4. Downhole unsmoothed curves for $\mathrm{Th} / \mathrm{Sc}$ and $\mathrm{Cr} / \mathrm{Th}$ values for (a) Dead Bullock Soak (DBS), composite core (Lambeck et al. 2008) and (b) Mount Charles composite core. The $\mathrm{Th} / \mathrm{Sc}$ and the $\mathrm{Cr} / \mathrm{TH}$ values for DBS show inverse trends. The Killi Killi Formation has high $\mathrm{Th} / \mathrm{Sc}$ and is assigned a felsic provenance. The Dead Bullock Formation has low $\mathrm{Th} / \mathrm{Sc}$ and high $\mathrm{Cr} / \mathrm{Th}$ interpreted to reflect a mafic provenance. The Mount Charles Formation has low $\mathrm{Th} / \mathrm{Sc}$ values and high $\mathrm{Cr} / \mathrm{Th}$ abundances also interpreted to have a mafic provenance. 
a)

Dead Bullock Soak Stratigraphy
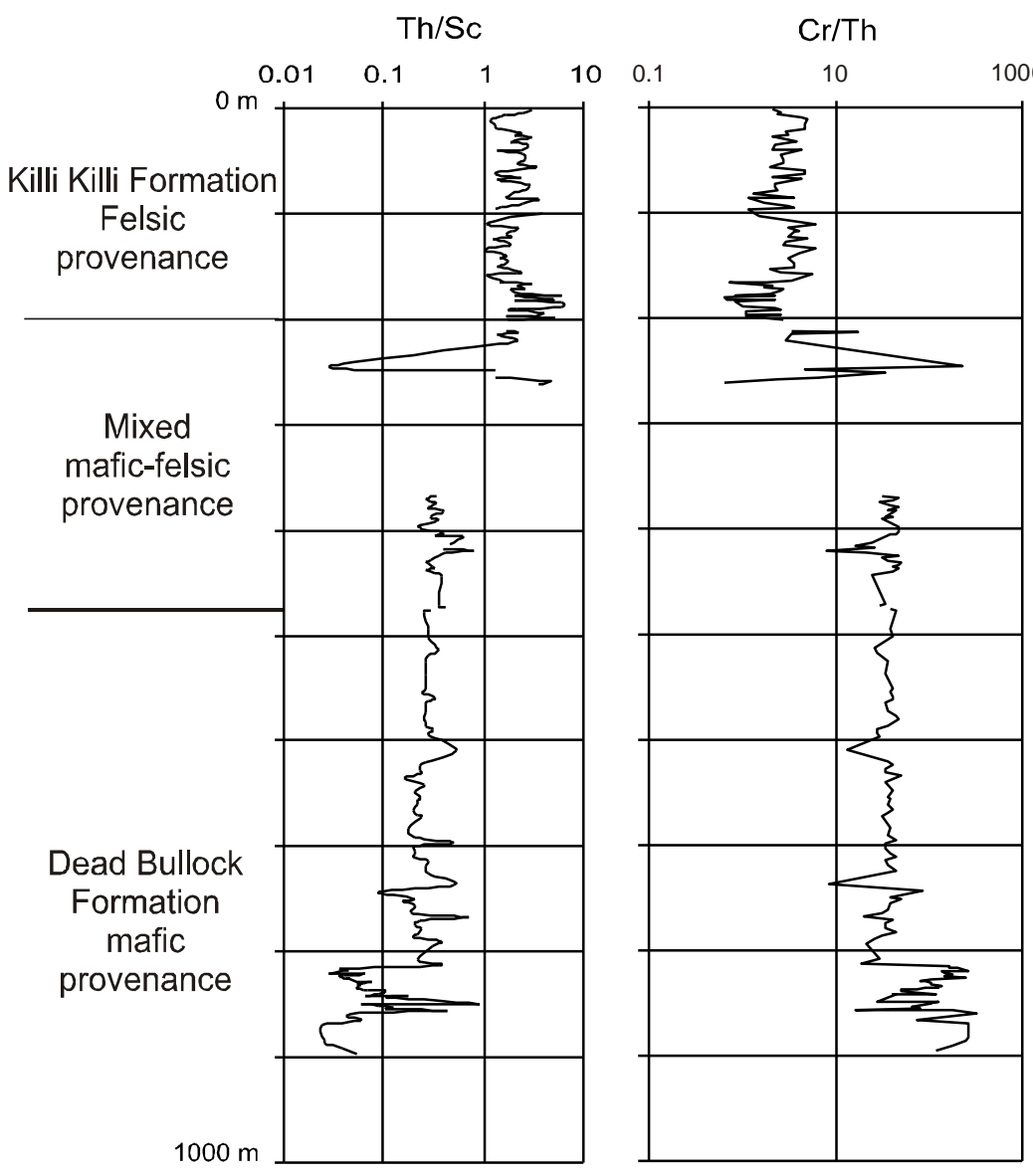

Drill hole

000

b)

Th/Sc

$\mathrm{Cr} / \mathrm{Th}$

Drill hole

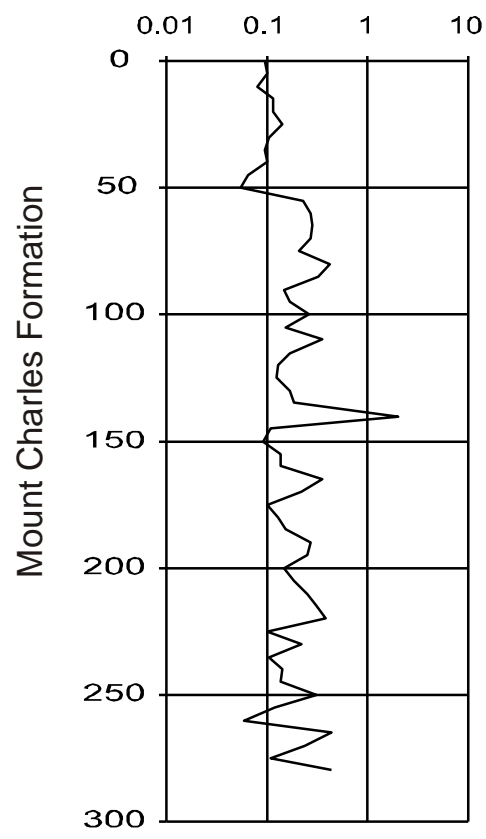

$\begin{array}{lll}0.1 & 10 & 1000\end{array}$

$(\mathrm{n}=127)$

DBD 419
$(n=16)$

DBD 434

$(\mathrm{n}=76)$

DBD 437

$(n=27)$

DBD 431

$(n=36)$

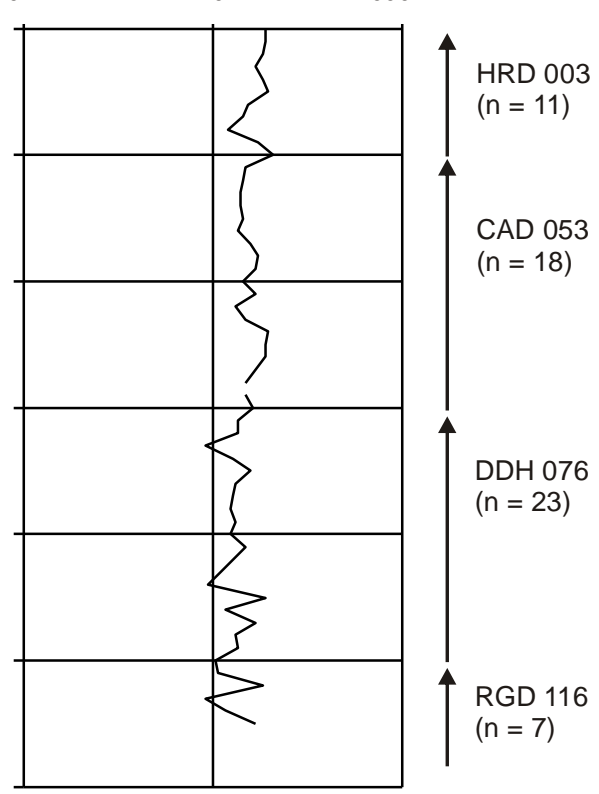

Fig. 5. $\mathrm{Cr} / \mathrm{Th}$ - $\mathrm{Th} / \mathrm{Sc}$ compositions of the Tanami regional stratigraphy. The Dead Bullock and Killi Killi Formations described in Lambeck et al. (2008) are used as a template for the regional straigraphy. Black squares are as follows: Archean crust - AC; Total continental crust - TCC; North American shale composition - NASC; Post-Archean average Australian shale - PAAS; Upper continental crust - UCC; (Taylor and McLennan 1985). 


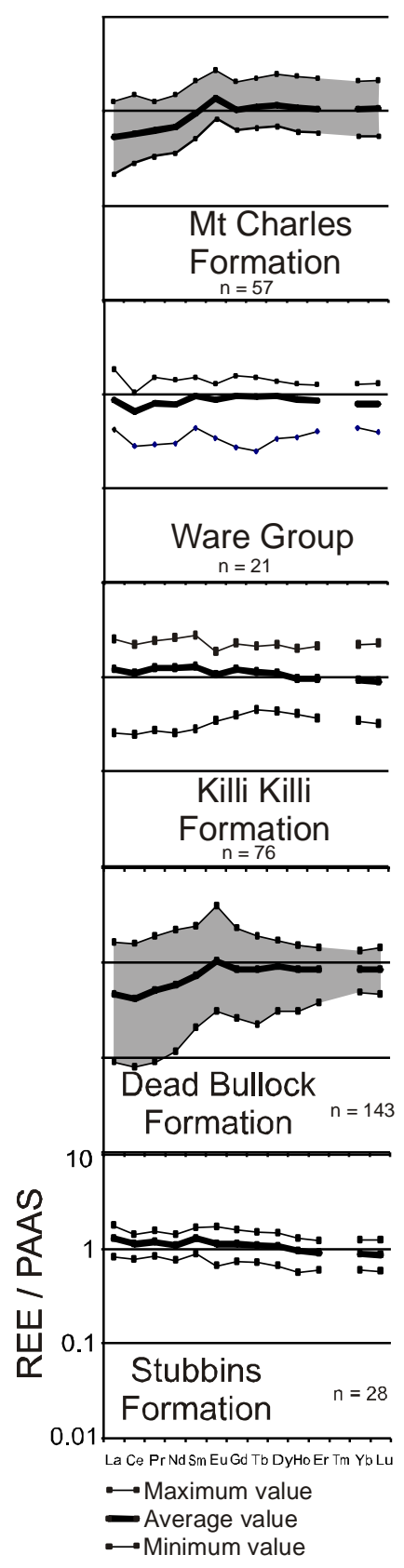

Fig. 6. REE pattern for each sedimentary regional stratigraphic unit in stratigraphic order normalised to PAAS (Taylor and McLennan, 1985). The Dead Bullock and Mount Charles Formations, which are the major gold-bearing units are characterised by moderate depletion in LREE and are highlighted in grey. In contrast, the Stubbins Formation, Killi Killi Formation, and Ware Group REE patterns are flat. 


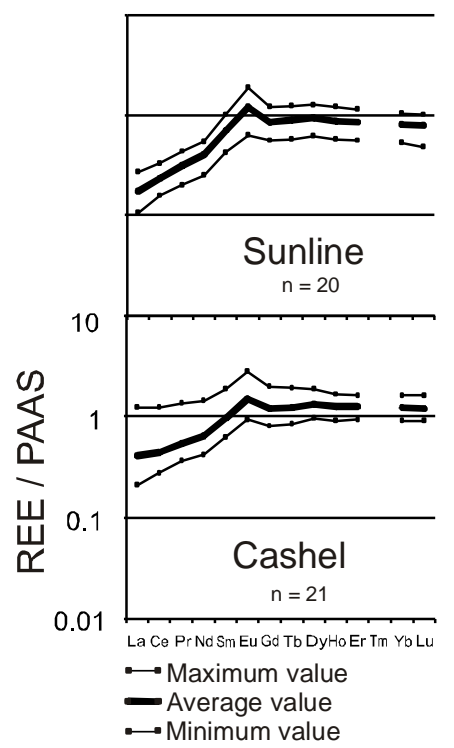

Fig. 7. The Cashel and Sunline prospect REE patterns are characterised by LREE depletion relative to HREE.

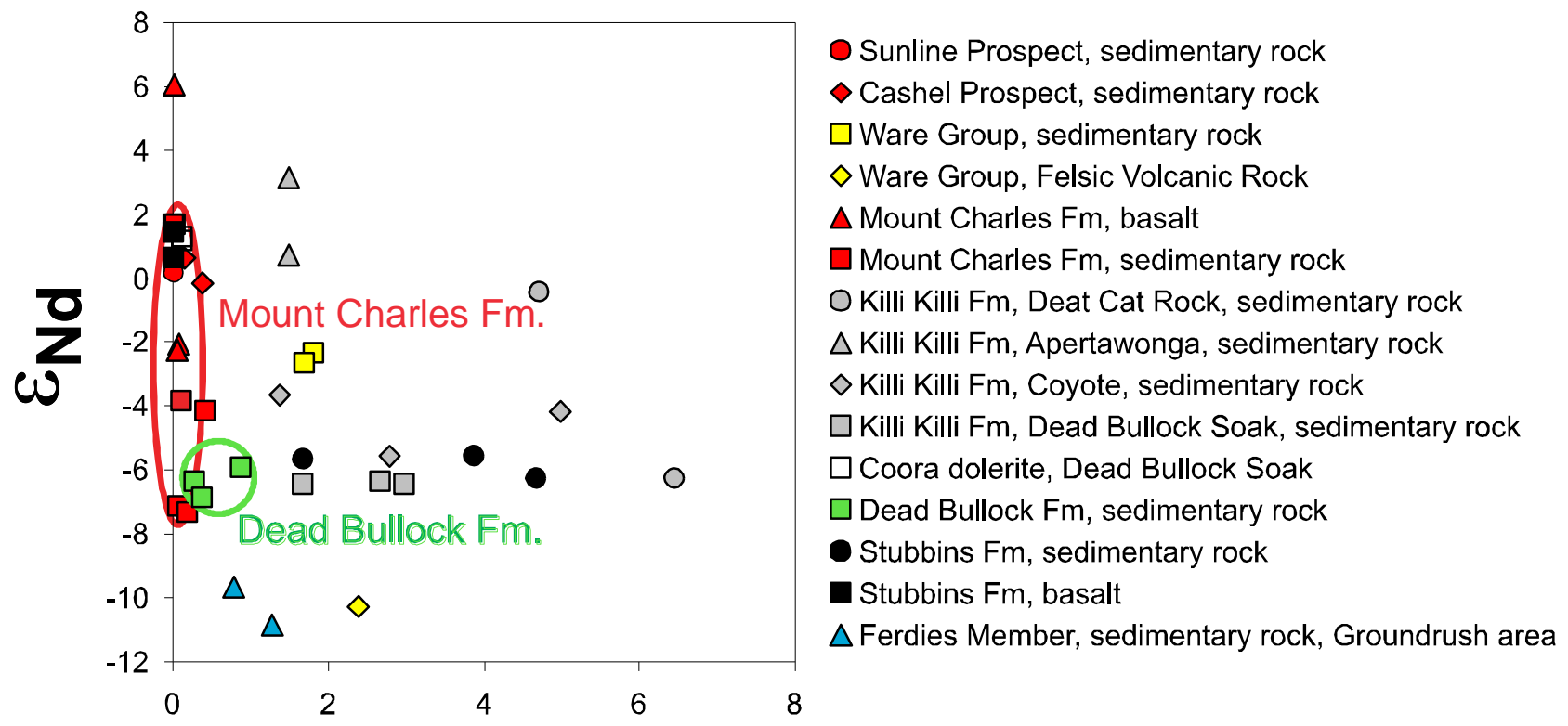

\section{Th/Sc}

Fig. 8. $\varepsilon_{\mathrm{Nd}}$ initial values plotted against $\mathrm{Th} / \mathrm{Sc}$ help differentiate the Tanami regional stratigraphy. 
Northern Tanami

Mount Charles Formation

deposition $\sim 1810 \mathrm{Ma}$, extension, mafic provenance (no zircon) granite emplacement $\sim 1790-1815 \mathrm{Ma}$

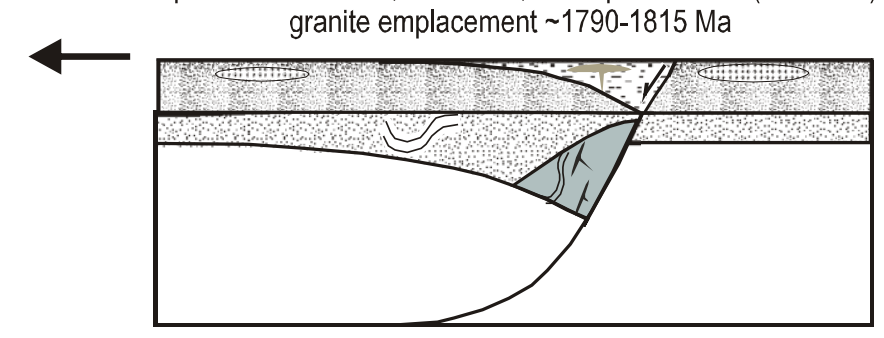

Event

Event 5

$\rightarrow \mathrm{Cr} / \mathrm{Th}>10$

$\mathrm{Th} / \mathrm{Sc}<1$

Ware Group

deposition $\sim 1820 \mathrm{Ma}$

regional extension, felsic provenance

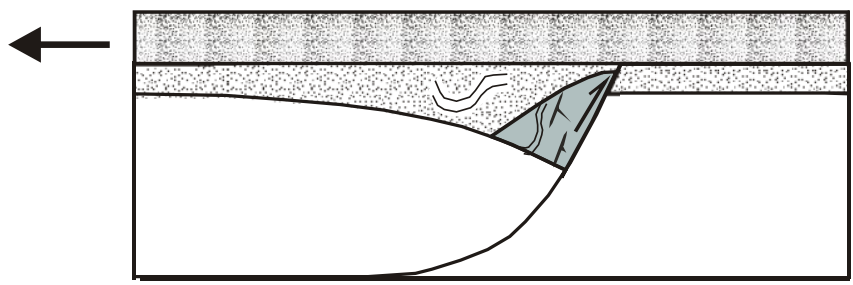

Event 4

$\mathrm{Cr} / \mathrm{Th}<2$

$\mathrm{Th} / \mathrm{Sc}>2$

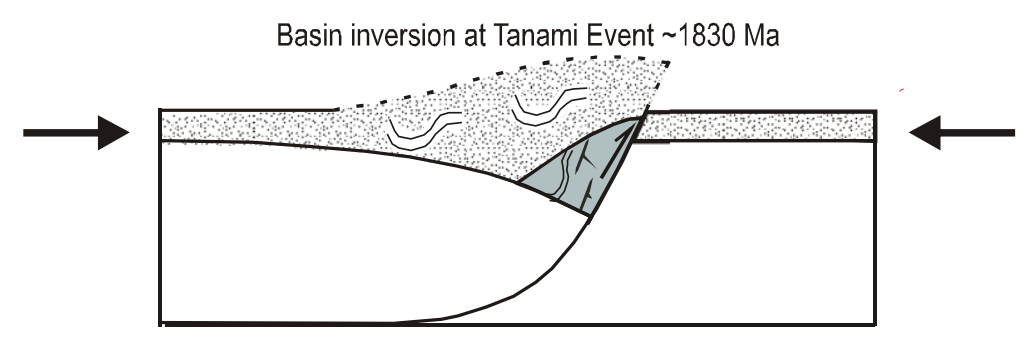

Killi Killi Fm - Broader basin

deposition $\sim 1840 \mathrm{Ma}$ (maximum deposition)

regional extension, felsic provenance, minor Archean input

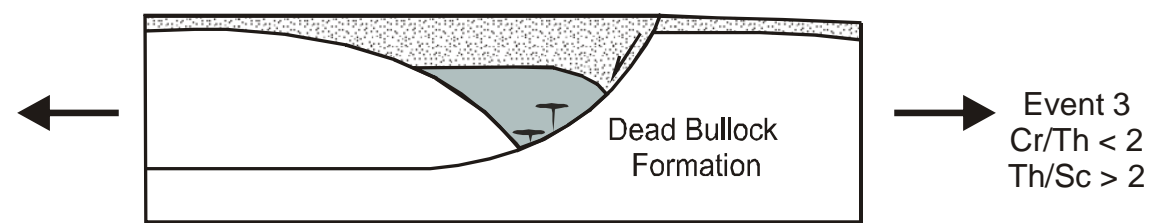

Dead Bullock Formation deposition $1838 \mathrm{Ma}$ (magmatic)

regional extension, mafic provenance, (minor zircon)

Western Tanami

Stubbins Formation deformation $\sim 1850 \mathrm{Ma}$

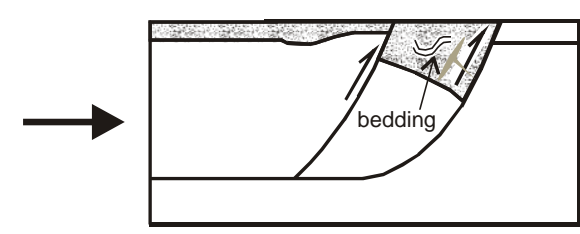

deposition $\sim 1864 \mathrm{Ma}$

local extension, felsic provenance

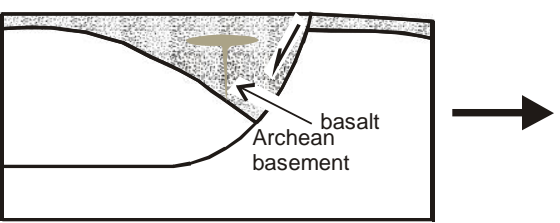

Event 1

$\mathrm{Cr} / \mathrm{Th}<2$

$\mathrm{Th} / \mathrm{Sc}>2$ 
Fig. 9. Schematic tectonic reconstruction models for the five main geochemical events in the Tanami region.
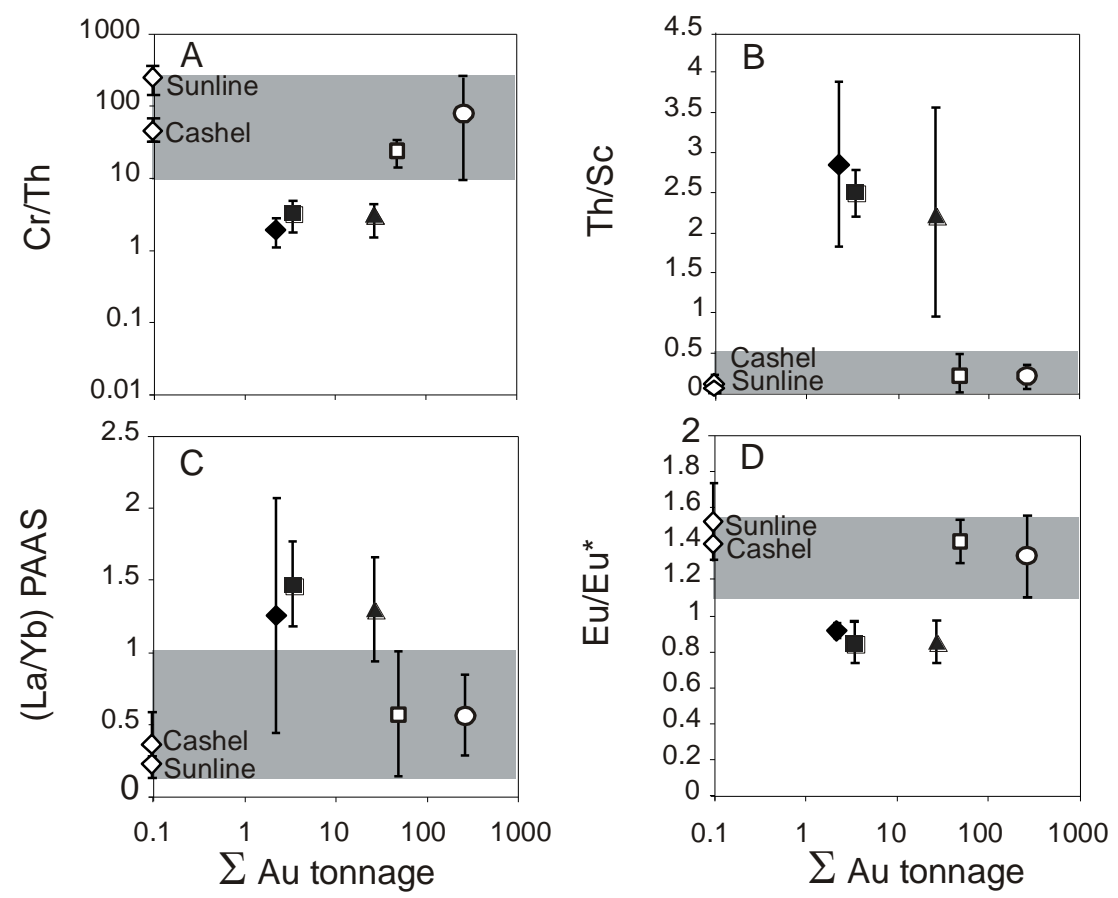

口 Mount Charles Formation

- Ware Group

- Killi Killi Formation

- Dead Bullock Formation

- Stubbins Formation

Fig. 10a. Total gold tonnage plotted against $\mathrm{Cr} / \mathrm{Th}$. For this case, total gold tonnage was calculated as the sum of gold resources, production and stockpile, error bars show \pm 1 standard deviation. Major gold bearing formations are shaded in grey. Dead Bullock and Mount Charles Formations are clearly distinguished by Cr/Th values $>10$.

Fig. 10b. Gold Tonnage plotted against $\mathrm{Th} / \mathrm{Sc}$, the Dead Bullock and Mount Charles Formations are distinguished by $\mathrm{Th} / \mathrm{Sc}$ values $<1$.

Fig. 10c. Gold Tonnage plotted against $(\mathrm{La} / \mathrm{Yb})_{\text {PAAS }}$ further highlights the division of the regional stratigraphy in respect to gold mineralisation.

Fig. 10d. Gold Tonnage plotted against Eu/Eu*. Samples from Sunline and Cashel Prospects fall within the same range as the Dead Bullock and Mount Charles Formation. 


\begin{tabular}{|c|c|c|c|c|c|c|c|}
\hline $\begin{array}{l}\text { Regional } \\
\text { Stratigraphy }\end{array}$ & $\begin{array}{l}\text { Total } \\
\mathrm{Au} \\
\text { (tonnes) }\end{array}$ & $\begin{array}{l}\text { Average } \\
\mathrm{Cr} / \mathrm{Th}\end{array}$ & $\begin{array}{l}\text { Average } \\
\mathrm{Th} / \mathrm{Sc}\end{array}$ & Average REE (PAAS) & $\mathrm{Eu} / \mathrm{Eu}^{*}$ & $\varepsilon \mathrm{Nd}$ & Geochronology \\
\hline $\begin{array}{l}\text { Mount } \\
\text { Charles } \\
\text { Formation }\end{array}$ & 56.6 & $22.2 \pm 9.8$ & $<1$ & {$[L a / Y b]_{P A A S}=0.5($ range $=0.1-3.4)$} & $1.4 \pm 0.1$ & $\begin{array}{l}\text { Range, } \\
-7.2 \text { to } \\
+1.6\end{array}$ & $\begin{array}{l}1800 \mathrm{Ma}(\mathrm{dep} \\
\text { age)(Cross and } \\
\text { Crispe 2006) }\end{array}$ \\
\hline Ware Group & 2.3 & $1.9 \pm 1.2$ & $2.9 \pm 1.2$ & {$[\mathrm{La} / \mathrm{Yb}]_{\mathrm{PAAS}}=1.1($ range $=0.3-2.7)$} & $0.9 \pm 0.1$ & $-2.4,-2.7$ & $\begin{array}{l}1815 \pm 13 \mathrm{Ma}, \\
\text { max dep } \\
\text { (Claoue-Long et } \\
\text { al. 2001) }\end{array}$ \\
\hline $\begin{array}{l}\text { Killi Killi } \\
\text { Formation }\end{array}$ & 33 & $2.7 \pm 1.3$ & $2.1 \pm 0.8$ & {$[\mathrm{La} / \mathrm{Yb}]_{\mathrm{PAAS}}=1.3($ range $=0.5-2.4)$} & $0.9 \pm 0.1$ & $\begin{array}{l}\text { Range, } \\
-6.5 \text { to } \\
+3.1\end{array}$ & $\begin{array}{l}\sim 1860 \mathrm{Ma}(\max \\
\text { dep) (Cross and } \\
\text { Crispe 2007) }\end{array}$ \\
\hline $\begin{array}{l}\text { Dead } \\
\text { Bullock } \\
\text { Formation }\end{array}$ & 270 & $63.5 \pm 45.6$ & $<1$ & $\begin{array}{l}{[L a / Y b]_{P A A S}=0.5, \text { with } 98 \% \text { of the data in the }} \\
\text { range of 0.1-1.0) }\end{array}$ & $1.3 \pm 0.2$ & $\begin{array}{l}\text { Range, } \\
-6.0 \text { to } \\
6.4\end{array}$ & $\begin{array}{l}1838 \pm 6 \text { Ma (max } \\
\text { dep) (Cross and } \\
\text { Crispe 2007) }\end{array}$ \\
\hline
\end{tabular}

Table 1. Summary of regional stratigraphy for the Tanami region in respect to total gold tonnage. Average and standard deviation for whole-rock and trace element geochemistry of sedimentary rock, Nd isotopes and geochronology. The Dead Bullock and Mt Charles Formations, shown in italics, are the main gold-bearing lithologies and are used as gold 'proxies' for further exploration in the Tanami region. Maximum deposition (max dep). 


\begin{tabular}{|c|c|c|c|c|c|c|c|c|c|c|c|c|c|c|c|}
\hline $\begin{array}{l}\text { Regional } \\
\text { stratigraphy }\end{array}$ & $\begin{array}{l}\text { Stubbins } \\
\text { Formation }\end{array}$ & $\begin{array}{l}\text { Stubbins } \\
\text { Formation }\end{array}$ & $\begin{array}{l}\text { Stubbins } \\
\text { Formation }\end{array}$ & $\begin{array}{l}\text { Dead } \\
\text { Bullock } \\
\text { Formation }\end{array}$ & $\begin{array}{l}\text { Dead } \\
\text { Bullock } \\
\text { Formation }\end{array}$ & $\begin{array}{l}\text { Dead } \\
\text { Bullock } \\
\text { Formation }\end{array}$ & $\begin{array}{l}\text { Killi Killi } \\
\text { Formation }\end{array}$ & $\begin{array}{l}\text { Killi Killi } \\
\text { Formation }\end{array}$ & $\begin{array}{l}\text { Killi Killi } \\
\text { Formation }\end{array}$ & Ware Group & Ware Group & Ware Group & $\begin{array}{l}\text { Mount } \\
\text { Charles } \\
\text { Formation }\end{array}$ & $\begin{array}{l}\text { Mount } \\
\text { Charles } \\
\text { Formation }\end{array}$ & $\begin{array}{l}\text { Mount } \\
\text { Charles } \\
\text { Formation }\end{array}$ \\
\hline Sample no. & $2004085495^{\mathrm{a}}$ & $2004085523^{\mathrm{a}}$ & $2004085535^{\mathrm{a}}$ & $2003085201^{a}$ & $2003085092^{a}$ & $2003085280^{\mathrm{a}}$ & $2003085073^{\mathrm{a}}$ & $2003085072^{\mathrm{a}}$ & $2003085071^{a}$ & $2005085302^{a}$ & $2005085303^{\mathrm{a}}$ & $2005085307^{\mathrm{a}}$ & $2005085134^{a}$ & $2005085115^{\mathrm{a}}$ & $2005085146^{\mathrm{a}}$ \\
\hline Lithology & Mudstone & Mudstone & Mudstone & Claystone & Claystone & Claystone & $\begin{array}{l}\text { Fine } \\
\text { sandstone }\end{array}$ & $\begin{array}{l}\text { V.Fine } \\
\text { sandstone }\end{array}$ & $\begin{array}{l}\text { V.Fine } \\
\text { sandstone }\end{array}$ & $\begin{array}{l}\text { Fine } \\
\text { sandstone }\end{array}$ & $\begin{array}{l}\text { Fine } \\
\text { sandstone }\end{array}$ & $\begin{array}{l}\text { Fine } \\
\text { sandstone }\end{array}$ & $\begin{array}{l}\text { Fine } \\
\text { sandstone }\end{array}$ & Mudstone & $\begin{array}{l}\text { Fine } \\
\text { sandstone }\end{array}$ \\
\hline Latitude & -19.58487 & -19.58487 & -19.58487 & -20.52238 & -20.52238 & -20.52238 & -20.50879 & -20.50879 & -20.50879 & -18.772308 & -18.676926 & -18.254666 & -20.039568 & -20.103263 & -20.103263 \\
\hline Longitude & 128.8657 & 128.8657 & 128.8657 & 130.944 & 130.944 & 130.944 & 129.9531 & 129.9531 & 129.9531 & 130.300775 & 130.338918 & 130.149407 & 129.669338 & 129.540473 & 129.540473 \\
\hline $\mathrm{SiO}_{2}$ & 61.9 & 64.2 & 61.1 & 56.1 & 57.7 & 65.7 & 72.1 & 77.9 & 56.2 & 62.9 & 89.8 & 81.0 & 61.6 & 44.2 & 55.3 \\
\hline $\mathrm{TiO}_{2}$ & 0.5 & 0.6 & 0.5 & 1.5 & 0.9 & 0.9 & 0.6 & 0.5 & 0.6 & 0.4 & 0.3 & 0.3 & 0.8 & 1.9 & 2.3 \\
\hline $\mathrm{Al}_{2} \mathbf{O}$ & 18.4 & 18.1 & 18.2 & 16.0 & 14.8 & 14.3 & 14.3 & 10.8 & 21.5 & 18.6 & 5.1 & 8.1 & 11.4 & 19.2 & 17.2 \\
\hline $\mathrm{Fe}_{2} \mathrm{O}_{3}$ & 5.8 & 5.4 & 6.5 & 14.4 & 11.7 & 9.4 & 2.9 & 3.4 & 8.8 & 7.3 & 1.2 & 4.3 & 11.6 & 21.3 & 15.7 \\
\hline MnO & $<0.1$ & $<0.1$ & $<0.1$ & 0.1 & 0.1 & $<0.1$ & $<0.1$ & $<0.1$ & $<0.1$ & $<0.1$ & $<0.1$ & $<0.1$ & 0.2 & 0.1 & $<0.1$ \\
\hline $\mathrm{MgO}$ & 2.7 & 1.7 & 2.7 & 4.2 & 5.3 & 2.1 & 0.7 & 1.0 & 2.1 & 1.0 & 0.2 & 0.9 & 3.6 & 2.9 & 0.4 \\
\hline $\mathrm{CaO}$ & 0.4 & 0.2 & 0.2 & 1.2 & 1.2 & 0.4 & 0.2 & 0.2 & 0.2 & 0.1 & 0.0 & 0.1 & 2.4 & 1.0 & 0.2 \\
\hline $\mathrm{Na}_{2} \mathrm{O}$ & 0.4 & 0.5 & 0.2 & 1.3 & 2.8 & 0.5 & 1.4 & 0.3 & 0.2 & 0.1 & $<0.1$ & 0.3 & 0.2 & 0.6 & 0.2 \\
\hline $\mathrm{K}_{2} \mathrm{O}$ & 5.6 & 5.2 & 5.3 & 1.9 & 1.0 & 3.4 & 4.1 & 4.5 & 5.7 & 5.4 & 1.1 & 0.7 & 1.8 & 4.7 & 4.4 \\
\hline $\mathbf{P}_{2} \mathbf{O}_{5}$ & 0.1 & 0.1 & 0.1 & 0.1 & 0.2 & 0.1 & 0.2 & 0.1 & 0.1 & 0.1 & 0.1 & 0.1 & 0.1 & 0.1 & 0.1 \\
\hline $\mathrm{SO}_{3}$ & 1.2 & 0.0 & 0.7 & 1.5 & 0.1 & 0.1 & 0.0 & 0.0 & 0.2 & $<0.1$ & 0.0 & 0.0 & 0.0 & 0.0 & 0.0 \\
\hline LOI & 2.7 & 3.7 & 4.4 & 2.1 & 4.1 & 2.9 & 3.2 & 1.1 & 4.2 & 3.9 & 2.1 & 3.9 & 6.2 & 3.8 & 4.0 \\
\hline Total & 99.8 & 99.8 & 99.8 & 100.5 & 100.0 & 100.1 & 99.9 & 99.9 & 100.0 & 99.8 & 99.9 & 99.9 & 99.9 & 99.8 & 99.9 \\
\hline Cs & 18.5 & 26.5 & 22.3 & 2.4 & 3.6 & 2.6 & 8.5 & 7.2 & 7.8 & 28.1 & 2.5 & 1.7 & 3.1 & 5.0 & 3.8 \\
\hline Ba & 1017.0 & 450.0 & 517.0 & 1445.0 & 126.0 & 997.0 & 312.0 & 404.0 & 726.0 & 738.0 & 155.0 & 165.0 & 192.0 & 363.0 & 105.0 \\
\hline $\mathbf{R b}$ & 258.7 & 266.8 & 265.9 & 81.8 & 49.0 & 83.6 & 307.1 & 322.5 & 298.7 & 302.8 & 76.6 & 54.4 & 50.4 & 138.3 & 122.0 \\
\hline Sr & 23.3 & 20.2 & 25.1 & 357.7 & 75.2 & 32.8 & 33.5 & 30.8 & 46.9 & 45.5 & 334.6 & 67.0 & 26.7 & 27.8 & 23.1 \\
\hline $\mathbf{P b}$ & 12.0 & 22.0 & 24.0 & 13.0 & 15.0 & 5.0 & 10.0 & 4.0 & 21.0 & 16.0 & 4.0 & 8.0 & 5.0 & 6.0 & 3.0 \\
\hline $\mathbf{L a}$ & 49.9 & 54.9 & 57.7 & 18.5 & 28.2 & 3.4 & 48.0 & 33.2 & 55.3 & 42.6 & 31.3 & 70.3 & 11.2 & 14.1 & 16.9 \\
\hline $\mathrm{Ce}$ & 96.4 & 107.4 & 105.0 & 36.8 & 51.9 & 6.3 & 96.6 & 66.0 & 105.3 & 83.4 & 59.9 & 81.6 & 22.4 & 38.5 & 41.4 \\
\hline Pr & 11.4 & 12.6 & 12.6 & 4.6 & 6.7 & 0.8 & 12.6 & 8.6 & 14.0 & 10.7 & 7.6 & 13.6 & 2.9 & 4.1 & 5.1 \\
\hline Nd & 39.9 & 43.1 & 42.2 & 18.1 & 26.1 & 3.7 & 43.1 & 30.6 & 48.1 & 37.2 & 27.9 & 45.5 & 11.4 & 15.2 & 21.1 \\
\hline Sm & 8.8 & 8.6 & 8.6 & 3.9 & 5.2 & 1.1 & 8.4 & 6.1 & 9.2 & 7.4 & 5.9 & 8.4 & 2.9 & 3.4 & 4.9 \\
\hline Eu & 1.2 & 1.3 & 1.3 & 0.9 & 2.4 & 0.3 & 1.4 & 0.9 & 1.6 & 1.2 & 0.8 & 1.4 & 0.9 & 1.1 & 1.3 \\
\hline Gd & 6.4 & 6.6 & 5.5 & 3.4 & 4.8 & 1.2 & 6.3 & 4.8 & 6.8 & 6.1 & 2.9 & 6.1 & 2.9 & 3.4 & 4.1 \\
\hline Tb & 1.0 & 1.1 & 0.8 & 0.6 & 0.8 & 0.2 & 1.0 & 0.7 & 1.0 & 1.0 & 0.4 & 0.9 & 0.5 & 0.7 & 0.7 \\
\hline Dy & 5.6 & 5.9 & 4.4 & 3.6 & 5.3 & 1.4 & 5.2 & 4.0 & 5.3 & 6.1 & 2.3 & 4.1 & 3.0 & 4.1 & 4.7 \\
\hline Ho & 1.1 & 1.2 & 0.9 & 0.8 & 1.1 & 0.3 & 1.0 & 0.8 & 1.1 & 1.3 & 0.5 & 0.8 & 0.6 & 1.0 & 1.0 \\
\hline $\mathrm{Er}$ & 3.3 & 3.2 & 2.5 & 2.3 & 3.4 & 1.1 & 3.0 & 2.3 & 3.1 & 3.7 & 1.6 & 2.1 & 1.7 & 2.6 & 2.9 \\
\hline $\mathbf{Y b}$ & 3.0 & 3.0 & 2.4 & 2.2 & 2.7 & 1.4 & 2.9 & 2.2 & 2.9 & 3.3 & 1.6 & 1.9 & 1.5 & 2.6 & 2.9 \\
\hline Lu & 0.4 & 0.4 & 0.4 & 0.4 & 0.3 & 0.2 & 0.4 & 0.3 & 0.5 & 0.5 & 0.2 & 0.3 & 0.2 & 0.4 & 0.5 \\
\hline $\mathbf{Y}$ & 35.1 & 37.8 & 24.2 & 19.3 & 34.7 & 8.7 & 31.0 & 25.2 & 32.7 & 42.5 & 16.2 & 26.9 & 19.4 & 19.1 & 27.2 \\
\hline Th & 19.6 & 22.8 & 17.7 & 8.2 & 20.5 & 2.3 & 24.6 & 20.2 & 24.0 & 27.6 & 15.8 & 15.5 & 7.9 & 4.6 & 4.6 \\
\hline $\mathbf{U}$ & 7.3 & 6.6 & 5.3 & 2.4 & 6.1 & 0.4 & 4.1 & 4.8 & 3.2 & 5.1 & 1.8 & 1.7 & 0.7 & 0.6 & 0.8 \\
\hline $\mathrm{Zr}$ & 110.0 & 180.0 & 102.0 & 169.0 & 148.0 & 67.0 & 243.0 & 216.0 & 121.0 & 141.1 & 144.4 & 295.5 & 99.6 & 152.7 & 175.8 \\
\hline Hf & 3.1 & 4.8 & 3.0 & 4.2 & 3.8 & 1.7 & 7.2 & 6.3 & 3.6 & 4.0 & 3.8 & 7.0 & 2.7 & 5.1 & 5.0 \\
\hline $\mathbf{N b}$ & 13.3 & 16.4 & 12.9 & 9.7 & 8.9 & 4.5 & 16.2 & 12.3 & 14.4 & 11.8 & 6.0 & 8.4 & 4.9 & 8.9 & 11.3 \\
\hline Sn & 6.9 & 8.5 & 6.9 & 1.7 & 1.2 & 2.0 & 8.5 & 5.3 & 7.0 & 6.5 & 2.1 & 8.5 & 0.8 & 1.9 & 1.6 \\
\hline Ta & 0.9 & 1.3 & 1.1 & 0.7 & 0.6 & 0.3 & 1.7 & 1.6 & 1.3 & 1.0 & 0.6 & 0.8 & 0.2 & 0.5 & 0.5 \\
\hline Mo & 0.9 & 0.5 & 1.0 & 1.3 & 1.6 & 1.4 & 1.1 & 1.5 & 0.7 & $<0.1$ & 2.1 & 5.4 & 0.5 & $<0.1$ & $<0.1$ \\
\hline $\mathrm{Cr}$ & 87.0 & 75.0 & 90.0 & 307.0 & 398.0 & 179.0 & 61.0 & 39.0 & 113.0 & 53.0 & 11.0 & 45.0 & 147.0 & 113.0 & 177.0 \\
\hline V & 81.0 & 67.0 & 94.0 & 230.0 & 197.0 & 285.0 & 58.0 & 34.0 & 103.0 & 74.0 & 11.0 & 40.0 & 164.0 & 327.0 & 321.0 \\
\hline Sc & 15.0 & 12.0 & 13.0 & 39.0 & 28.0 & 38.0 & 11.0 & 6.0 & 17.0 & 15.0 & 4.0 & 9.0 & 19.0 & 47.0 & 33.0 \\
\hline $\mathrm{Cu}$ & 42.0 & 23.0 & 273.0 & 95.0 & 62.0 & 69.0 & 53.0 & 26.0 & 25.0 & 1.0 & 1.0 & 4.0 & 137.0 & 94.0 & 35.0 \\
\hline Zn & 145.0 & 90.0 & 131.0 & 148.0 & 92.0 & 64.0 & 15.0 & 22.0 & 45.0 & 94.0 & 4.0 & 40.0 & 119.0 & 160.0 & 55.0 \\
\hline
\end{tabular}




\begin{tabular}{|c|c|c|c|c|c|c|c|c|c|c|c|c|c|c|c|}
\hline $\mathbf{A g}$ & 4.5 & 1.0 & 0.8 & 0.2 & 0.1 & $<0.01$ & $<0.01$ & $<0.01$ & $<0.01$ & $<0.01$ & $<0.01$ & 6.4 & 26.5 & 2.4 & 15.6 \\
\hline As & $<0.1$ & 4.6 & 55.5 & $<0.4$ & 9.5 & $<0.4$ & 4.6 & 1.9 & 1.4 & 6.7 & 4.5 & 8.4 & 3.8 & 6.4 & 4.9 \\
\hline $\mathrm{Be}$ & 4.0 & 4.7 & 4.6 & 1.6 & 1.7 & 1.0 & 4.1 & 2.6 & 4.8 & 4.2 & 1.0 & 2.2 & 0.9 & 1.0 & 0.9 \\
\hline $\mathbf{B i}$ & 0.4 & 0.7 & 0.6 & 0.1 & 0.1 & $<0.01$ & 0.1 & 0.3 & 0.2 & 0.8 & $<0.1$ & 0.9 & $<0.1$ & 0.1 & $<0.1$ \\
\hline $\mathrm{Ga}$ & 26.5 & 24.6 & 23.7 & 22.1 & 17.4 & 16.8 & 21.4 & 13.8 & 29.8 & 25.5 & 6.6 & 10.7 & 16.3 & 27.2 & 27.3 \\
\hline $\mathbf{F}$ & 723.0 & 888.0 & 837.0 & 737.0 & 1140.0 & 723.0 & 1822.0 & 1283.0 & 1690.0 & 1888.0 & 512.0 & 2009.0 & 266.0 & $<37$ & 161.0 \\
\hline Ge & 1.5 & 1.7 & 1.8 & 2.0 & 2.9 & 2.8 & 1.9 & 1.8 & 2.3 & 1.9 & 1.0 & 2.1 & 1.6 & 1.6 & 2.2 \\
\hline Sb & 3.1 & 1.9 & 8.2 & 4.6 & 0.5 & 0.2 & 1.5 & 5.1 & 1.0 & 8.3 & 4.4 & 4.4 & 0.8 & 1.8 & 7.6 \\
\hline $\mathbf{L a} / \mathbf{S c}$ & 3.3 & 4.6 & 4.4 & 0.5 & 1.0 & 0.1 & 4.4 & 5.5 & 3.3 & 2.8 & 7.8 & 7.8 & 0.6 & 0.3 & 0.5 \\
\hline $\mathrm{Zr} / \mathrm{Sc}$ & 7.3 & 15.0 & 7.8 & 4.2 & 5.2 & 1.8 & 22.8 & 38.9 & 7.1 & 9.4 & 36.1 & 32.8 & 5.2 & 3.2 & 5.3 \\
\hline $\begin{array}{l}\mathbf{T h} / \mathbf{S c} \\
(\mathbf{L} / \mathbf{Y} \mathbf{Y b})\end{array}$ & 1.3 & 1.9 & 1.4 & 0.2 & 0.7 & 0.1 & 2.2 & 3.4 & 1.4 & 1.8 & 4.0 & 1.7 & 0.4 & 0.1 & 0.1 \\
\hline & 1.2 & 1.3 & 1.8 & 0.6 & 0.8 & 0.2 & 1.2 & 1.1 & 1.4 & 1.0 & 1.4 & 2.7 & 0.6 & 0.4 & 0.4 \\
\hline Eu/Eu* & 0.7 & 0.8 & 0.9 & 0.7 & 1.5 & 0.9 & 0.5 & 0.5 & 0.6 & 0.9 & 0.9 & 0.9 & 1.5 & 1.5 & 1.4 \\
\hline
\end{tabular}

Table 2. Representative samples from the Tanami regional stratigraphy, all data is found in Supplementary paper.

Major elements reported in oxide weight percent, trace elements reported in parts per million, Eu/Eu* $=(\mathrm{Eu} / 1.1) /((\mathrm{Sm} / 5.6+\mathrm{Gd} / 4.7) / 2)$. Subscript PAAS refers to PAAS normalised ratios; normalising factors from Taylor and McLennan (1985). Elements in italics and listed here contain contamination from grinding wheel and analysis of the contaminated elements has not been used in this study, $\mathrm{Fe} 2 \mathrm{O} 3, \mathrm{MnO}, \mathrm{Cu}, \mathrm{Zn}, \mathrm{Ag}$. 


\begin{tabular}{|c|c|c|c|c|c|c|c|c|c|c|c|c|c|c|}
\hline $\begin{array}{l}\text { Sample \# } \\
\text { (laboratory) }\end{array}$ & $\begin{array}{l}\text { Regional } \\
\text { Stratigraphy }\end{array}$ & Longitude & Latitude & $\begin{array}{l}\text { Depth } \\
\text { m }\end{array}$ & $\begin{array}{l}\text { Prospect/local } \\
\text { name/drill core }\end{array}$ & Lithology & $\begin{array}{l}\text { Age } \\
(\mathrm{Ma})\end{array}$ & $\begin{array}{l}\text { Sm } \\
\mathrm{ppm}\end{array}$ & $\begin{array}{l}\text { Nd } \\
\text { ppm }\end{array}$ & ${ }^{147} \mathrm{Sm} /{ }^{144} \mathrm{Nd}$ & ${ }^{143} \mathrm{Nd} /{ }^{144} \mathrm{Nd}$ & 2SE & $\begin{array}{l}\varepsilon_{\mathrm{Nd}} \\
(\varnothing \mathrm{Ma})\end{array}$ & $\begin{array}{l}\varepsilon_{N d} \\
(t)\end{array}$ \\
\hline $\begin{array}{l}2005085051 \\
\text { (A) }\end{array}$ & $\begin{array}{l}\text { Mount } \\
\text { Charles } \\
\text { Formation }\end{array}$ & 130.94396 & -20.522376 & 140.5 & Cashel/002 & Sandy SIst. & 1810 & 4.9 & 18.0 & 0.1637 & 0.512276 & 20 & -7.1 & +0.6 \\
\hline $\begin{array}{l}2005085064 \\
\text { (A) }\end{array}$ & $\begin{array}{l}\text { Mount } \\
\text { Charles } \\
\text { Formation }\end{array}$ & 130.94396 & -20.522376 & 83.0 & Cashel /002 & Sandy Slst. & 1810 & 7.6 & 41.0 & 0.1118 & 0.511618 & 20 & -19.9 & -0.2 \\
\hline $\begin{array}{l}2005085083 \\
\text { (A) }\end{array}$ & $\begin{array}{l}\text { Mount } \\
\text { Charles } \\
\text { Formation }\end{array}$ & 130.084303 & -19.566657 & 178.0 & Sunline/HYD003 & Sandy Slst. & 1810 & 4.5 & 17.6 & 0.1542 & 0.512138 & 20 & -9.8 & +0.1 \\
\hline $\begin{array}{l}2005085203 \\
\text { (B) }\end{array}$ & $\begin{array}{l}\text { Mount } \\
\text { Charles } \\
\text { Formation }\end{array}$ & 129.6670772 & -20.058092 & $\begin{array}{l}\text { Outcrop } \\
\text { sample } \\
\text { from pit }\end{array}$ & Dinky bouncer & Basalt & 1810 & 4.9 & 21.5 & 0.1386 & 0.512301 & 8.7 & -7.5 & +6.0 \\
\hline $\begin{array}{l}2005085145 \\
\text { (B) }\end{array}$ & $\begin{array}{l}\text { Mount } \\
\text { Charles } \\
\text { Formation }\end{array}$ & 129.716439 & -19.961145 & 60.7 & Hurricane/003 & $\begin{array}{l}\text { Poorly- } \\
\text { sorted c.-Sst. }\end{array}$ & 1810 & 4.8 & 20.2 & 0.1448 & 0.511703 & 11.2 & -19.2 & -7.2 \\
\hline $\begin{array}{l}2005085154 \\
\text { (A) }\end{array}$ & $\begin{array}{l}\text { Mount } \\
\text { Charles } \\
\text { Formation }\end{array}$ & 129.6861808 & -20.022533 & 26.0 & Money/RDG116 & $\begin{array}{l}\text { Poorly- } \\
\text { sorted c.-Sst. }\end{array}$ & 1810 & 7.6 & 29.6 & 0.1542 & 0.512213 & 20 & -8.3 & +1.6 \\
\hline $\begin{array}{l}2005085158 \\
\text { (B) }\end{array}$ & $\begin{array}{l}\text { Mount } \\
\text { Charles } \\
\text { Formation }\end{array}$ & 129.6861808 & -20.022533 & 111.0 & Money/RDG117 & Slst. & 1810 & 6.9 & 27.3 & 0.1526 & 0.511945 & 11.1 & -14.5 & -4.2 \\
\hline $\begin{array}{l}2005085202 \\
\text { (A) }\end{array}$ & $\begin{array}{l}\text { Mount } \\
\text { Charles } \\
\text { Formation }\end{array}$ & 129.6670531 & -20.022433 & $\begin{array}{l}\text { Outcrop } \\
\text { sample } \\
\text { from pit }\end{array}$ & Money/RDG118 & Basalt & 1810 & 6.2 & 23.4 & 0.1605 & 0.512098 & 20 & -10.5 & -2.1 \\
\hline $\begin{array}{l}2005085201 \\
\text { (B) }\end{array}$ & $\begin{array}{l}\text { Mount } \\
\text { Charles } \\
\text { Formation }\end{array}$ & 129.6670372 & -20.022520 & $\begin{array}{l}\text { Outcrop } \\
\text { sample } \\
\text { from pit }\end{array}$ & Southern Pit & Basalt & 1810 & 12.4 & 46.8 & 0.1598 & 0.512138 & 11.4 & -10.9 & -2.3 \\
\hline $\begin{array}{l}2005085100 \\
\text { (A) }\end{array}$ & $\begin{array}{l}\text { Mount } \\
\text { Charles } \\
\text { Formation }\end{array}$ & 129.6670772 & -20.05809 & 96.5 & Dogbolter/076 & Slst. & 1810 & 7.1 & 37.5 & 0.1139 & 0.511451 & 20. & -23.2 & -3.9 \\
\hline $\begin{array}{l}2005085116 \\
\text { (B) }\end{array}$ & $\begin{array}{l}\text { Mount } \\
\text { Charles } \\
\text { Formation }\end{array}$ & 129.6670772 & -20.05809 & 201.8 & Dogbolter/076 & $\begin{array}{l}\text { Poorly- } \\
\text { sorted c.-Sst. }\end{array}$ & 1810 & 4.8 & 20.8 & 0.1388 & 0.511600 & 8.3 & -20.8 & -7.4 \\
\hline $\begin{array}{l}87495001 \\
\text { (B) }\end{array}$ & $\begin{array}{l}\text { Nanny Goat } \\
\text { Volcanics }\end{array}$ & 130.080408 & -19.107752 & $\begin{array}{l}\text { Outcrop } \\
\text { sample }\end{array}$ & Ware Group & $\begin{array}{l}\text { Felsic } \\
\text { Volcanic }\end{array}$ & 1820 & 1.8 & 7.5 & 0.1447 & 0.511562 & 16.4 & -22.4 & -10.3 \\
\hline $\begin{array}{l}2005085302 \\
\text { (A) }\end{array}$ & Ware Group & 130.3007753 & -18.772307 & $\begin{array}{l}\text { Outcrop } \\
\text { sample }\end{array}$ & Ware Group & Fine Sst. & 1820 & 7.1 & 36.5 & 0.1175 & 0.511565 & 20 & -20.9 & -2.4 \\
\hline $\begin{array}{l}2005085307 \\
\text { (A) }\end{array}$ & Ware Group & 130.1494073 & -18.254666 & $\begin{array}{l}\text { Outcrop } \\
\text { sample }\end{array}$ & Ware Group & Fine Sst & 1820 & 8.1 & 45.6 & 0.1073 & 0.511429 & 20 & -23.8 & -2.7 \\
\hline $\begin{array}{l}2004085415 \\
\text { (B) }\end{array}$ & $\begin{array}{l}\text { Killi Killi } \\
\text { Formation }\end{array}$ & 128.831278 & -19.899652 & 248.2 & Coyote CYD050 & $\begin{array}{l}\text { Poorly- } \\
\text { sorted c.-Sst. }\end{array}$ & 1840 & 5.9 & 32.7 & 0.1085 & 0.509975 & 8.2 & -26.7 & -5.6 \\
\hline $\begin{array}{l}2004085428 \\
\text { (A) }\end{array}$ & $\begin{array}{l}\text { Killi Killi } \\
\text { Formation }\end{array}$ & 128.831676 & -19.899966 & 315.0 & Coyote CYD072 & $\begin{array}{l}\text { Poorly- } \\
\text { sorted c.-Sst. }\end{array}$ & 1840 & 11.1 & 63.0 & 0.1067 & 0.511370 & 20 & -25.0 & -3.7 \\
\hline
\end{tabular}




\begin{tabular}{|c|c|c|c|c|c|c|c|c|c|c|c|c|c|c|}
\hline $\begin{array}{l}\text { Sample \# } \\
\text { (laboratory) }\end{array}$ & $\begin{array}{l}\text { Regional } \\
\text { Stratigraphy }\end{array}$ & Longitude & Latitude & Depth $\mathrm{m}$ & $\begin{array}{l}\text { Prospect/local } \\
\text { name/drill core }\end{array}$ & Lithology & $\begin{array}{l}\text { Age } \\
(\mathrm{Ma})\end{array}$ & $\begin{array}{l}\text { Sm } \\
\mathrm{ppm}\end{array}$ & $\begin{array}{l}\mathrm{Nd} \\
\mathrm{ppm}\end{array}$ & $\begin{array}{l}{ }^{147} \mathrm{Sm} / /^{144} \\
\mathrm{Nd}\end{array}$ & ${ }^{143} \mathrm{Nd} /{ }^{144} \mathrm{Nd}$ & 2SE & $\begin{array}{l}\varepsilon_{\mathrm{Nd}} \\
(\varnothing \mathrm{Ma})\end{array}$ & $\varepsilon_{N d}(t)$ \\
\hline $\begin{array}{l}2002082007 \\
\text { (A) }\end{array}$ & $\begin{array}{l}\text { Killi Killi } \\
\text { Formation }\end{array}$ & 128.831676 & -19.8999666 & 200.0 & Coyote CYD072 & $\begin{array}{l}\text { Poorly- } \\
\text { sorted c.- } \\
\text { Sst. }\end{array}$ & 1840 & 5.6 & 31.4 & 0.1083 & 0.511365 & 20 & -25.1 & -4.2 \\
\hline $\begin{array}{l}2004085003 \\
\text { (B) }\end{array}$ & $\begin{array}{l}\text { Killi Killi } \\
\text { Formation }\end{array}$ & 129.965654 & -20.539965 & $\begin{array}{l}\text { Outcrop } \\
\text { sample }\end{array}$ & Dead Cat Rock & $\begin{array}{l}\text { Poorly- } \\
\text { sorted c.- } \\
\text { Sst. }\end{array}$ & 1840 & 8.1 & 40.8 & 0.1199 & 0.509939 & 13.3 & $\begin{array}{l}-24.3 \\
\end{array}$ & $\begin{array}{c}-6.3 \\
\end{array}$ \\
\hline $\begin{array}{l}2004085001 \\
\text { (B) }\end{array}$ & $\begin{array}{l}\text { Killi Killi } \\
\text { Formation }\end{array}$ & 129.965654 & -20.539965 & $\begin{array}{l}\text { Outcrop } \\
\text { sample }\end{array}$ & Dead Cat Rock & $\begin{array}{l}\text { Poorly- } \\
\text { sorted c.- } \\
\text { Sst. }\end{array}$ & 1840 & 6.0 & 34.5 & 0.1043 & 0.411506 & 20 & -22.3 & -0.5 \\
\hline $\begin{array}{l}2005085301 \\
\text { (B) }\end{array}$ & $\begin{array}{l}\text { Killi Killi } \\
\text { Formation }\end{array}$ & 129.546003 & -20.23718 & $\begin{array}{l}\text { Outcrop } \\
\text { sample }\end{array}$ & Apertawonga & Mst. & 1840 & 3.4 & 22.4 & 0.0915 & 0.510296 & 15.4 & -24.1 & +0.7 \\
\hline $\begin{array}{l}2005085300 \\
\text { (A) }\end{array}$ & $\begin{array}{l}\text { Killi Killi } \\
\text { Formation }\end{array}$ & 129.545945 & -20.23719 & $\begin{array}{l}\text { Outcrop } \\
\text { sample }\end{array}$ & Apertawonga & Mst. & 1840 & 6.9 & 50.3 & 0.0830 & 0.511430 & 20 & -23.8 & +3.1 \\
\hline $\begin{array}{l}2003085079 \\
\text { (A) }\end{array}$ & $\begin{array}{l}\text { Killi Killi } \\
\text { Formation }\end{array}$ & 129.953133 & -20.508792 & 181.3 & Callie/DBD434 & Slst. & 1840 & 7.0 & 36.4 & 0.1167 & 0.511357 & 20 & -25.2 & -6.4 \\
\hline $\begin{array}{l}2003085089 \\
\text { (B) }\end{array}$ & $\begin{array}{l}\text { Killi Killi } \\
\text { Formation }\end{array}$ & 129.953133 & -20.508792 & 136.1 & Callie/DBD434 & Slst. & 1840 & 4.3 & 22.5 & 0.1164 & 0.509929 & 7.8 & -25.4 & -6.5 \\
\hline $\begin{array}{l}2003085091 \\
\text { (B) }\end{array}$ & $\begin{array}{l}\text { Killi Killi } \\
\text { Formation } \\
\end{array}$ & 129.953133 & -20.508792 & 127.7 & Callie/DBD434 & V.fine Sst & 1840 & 0.6 & 3.3 & 0.1160 & 0.509925 & 7.8 & -25.5 & -6.5 \\
\hline $\begin{array}{l}2004085004 \\
\text { (B) }\end{array}$ & $\begin{array}{l}\text { Dead Bullock } \\
\text { Formation }\end{array}$ & 129.932398 & -20.525999 & 185.0 & $\begin{array}{l}\text { Coora Dolerite } \\
\text { X885_2088 }\end{array}$ & Dolerite & 1840 & 1.5 & 5.1 & 0.1814 & 0.510342 & 8.8 & -2.0 & +1.6 \\
\hline $\begin{array}{l}2004085005 \\
\text { (B) }\end{array}$ & $\begin{array}{l}\text { Dead Bullock } \\
\text { Formation }\end{array}$ & 129.932398 & -20.525999 & 250.0 & $\begin{array}{l}\text { Coora Dolerite } \\
\text { X885_2089 }\end{array}$ & Dolerite & 1840 & 1.6 & 5.3 & 0.1847 & 0.510313 & 11.6 & -1.7 & +1.1 \\
\hline $\begin{array}{l}2003085265 \\
\text { (A) }\end{array}$ & $\begin{array}{l}\text { Dead Bullock } \\
\text { Formation }\end{array}$ & 129.914437 & -20.533068 & 327.5 & Orac/DBD440 & Slst. & 1838 & 4.7 & 23.2 & 0.1210 & 0.511371 & 20 & -24.7 & -6.9 \\
\hline $\begin{array}{l}2003085142 \\
\text { (A) }\end{array}$ & $\begin{array}{l}\text { Dead Bullock } \\
\text { Formation }\end{array}$ & 129.914437 & -20.533068 & 158.3 & $\begin{array}{l}\text { Upper Blake } \\
\text { Beds/DBD440 }\end{array}$ & Mst. & 1838 & 4.3 & 20.9 & 0.1254 & 0.511450 & 20 & -23.2 & $\begin{array}{c}-6.4 \\
\end{array}$ \\
\hline $\begin{array}{l}2003085289 \\
\text { (A) }\end{array}$ & $\begin{array}{l}\text { Dead Bullock } \\
\text { Formation }\end{array}$ & 129.922206 & -20.530549 & 574.3 & $\begin{array}{l}\text { Calli Laminated } \\
\text { Beds/DBD431 }\end{array}$ & Slst. & 1860 & 13.5 & 66.3 & 0.1229 & 0.511429 & 20 & -23.6 & -6.0 \\
\hline $\begin{array}{l}2004085327 \\
\text { (A) }\end{array}$ & $\begin{array}{l}\text { Ferdies } \\
\text { Member }\end{array}$ & 129.991425 & -19.712445 & 326.0 & Groundrush/GHD045 & $\begin{array}{l}\text { Poorly- } \\
\text { sorted c.- } \\
\text { Sst. }\end{array}$ & 1860 & 6.2 & 35.6 & 0.1045 & 0.510956 & 20 & -32.8 & -10.9 \\
\hline $\begin{array}{l}2004085340 \\
\text { (A) }\end{array}$ & $\begin{array}{l}\text { Ferdies } \\
\text { Member }\end{array}$ & 129.991425 & -19.712445 & 415.0 & Groundrush/GHD045 & $\begin{array}{l}\text { Poorly- } \\
\text { sorted c.- } \\
\text { Sst. }\end{array}$ & 1860 & 6.0 & 28.9 & 0.1255 & 0.511274 & 20 & -26.6 & $\begin{array}{l}-9.7 \\
\end{array}$ \\
\hline $\begin{array}{l}2004085464 \\
\text { (A) }\end{array}$ & $\begin{array}{l}\text { Stubbins } \\
\text { Formation }\end{array}$ & 128.865741 & -19.584874 & 388.9 & $\begin{array}{l}\text { Stubbins } \\
\text { Formation/BLRCD02 }\end{array}$ & $\begin{array}{l}\text { Poorly- } \\
\text { sorted m. - } \\
\text { Sst. }\end{array}$ & 1860 & 9.3 & 48.1 & 0.1162 & 0.511364 & 20 & -19.9 & -5.7 \\
\hline $\begin{array}{l}2004085467 \\
\text { (B) }\end{array}$ & $\begin{array}{l}\text { Stubbins } \\
\text { Formation }\end{array}$ & 128.864297 & -19.589202 & 205.2 & $\begin{array}{l}\text { Stubbins } \\
\text { Formation/LKD100 }\end{array}$ & $\begin{array}{l}\text { Poorly- } \\
\text { sorted m. - } \\
\text { Sst. }\end{array}$ & 1864 & 5.5 & 29.6 & 0.1125 & 0.511367 & 9.6 & -25.6 & -5.6 \\
\hline $\begin{array}{l}2004085504 \\
\text { (B) }\end{array}$ & $\begin{array}{l}\text { Stubbins } \\
\text { Formation }\end{array}$ & 128.863563 & -19.589147 & 164.0 & $\begin{array}{l}\text { Stubbins } \\
\text { Formation/LKD54 }\end{array}$ & $\begin{array}{l}\text { Poorly- } \\
\text { sorted m. - } \\
\text { Sst. }\end{array}$ & 1864 & 5.7 & 29.8 & 0.1156 & 0.511370 & 8.7 & -25.7 & $\begin{array}{l}-6.3 \\
\end{array}$ \\
\hline $\begin{array}{l}177280 \\
(\mathrm{~A})\end{array}$ & $\begin{array}{l}\text { Stubbins } \\
\text { Formation }\end{array}$ & 128.864297 & -19.589202 & 151.8 & $\begin{array}{l}\text { Stubbins } \\
\text { Formation/BLRCD01 }\end{array}$ & Basalt & 1860 & 2.9 & 10.9 & 0.1597 & 0.512216 & 20 & -8.2 & 0.6 \\
\hline $\begin{array}{l}178804 \\
\text { (B) }\end{array}$ & $\begin{array}{l}\text { Stubbins } \\
\text { Formation }\end{array}$ & 128.865741 & -19.584874 & 123.7 & $\begin{array}{l}\text { Stubbins } \\
\text { Formation/BLRCD01 }\end{array}$ & Basalt & 1860 & 4.1 & 14.5 & 0.1695 & 0.512375 & 20 & -5.1 & 1.4 \\
\hline
\end{tabular}


Table 3. Sm-Nd isotope data for selected regional Tanami samples, locations in GDA 94. Mst. - mudstone; Slst. - siltstone; Sst - sandstone; m.Sst. - medium-sandstone; c.Sst - coarse-sandstone. $(\mathrm{A})=$ La Trobe University, $(\mathrm{B})=$ Adelaide University, $2 \mathrm{SE}=0.511289 \pm 0.00002$. 


\section{References}

Bagas L, Anderson JAC, Bierlein FP (2009) Palaeoproterozoic evolution of the Killi Killi Formation and orogenic gold mineralization in the Granites-Tanami Orogen, Western Australia. Ore Geology Reviews 35: 47-67.

Bagas L, Bierlein FP, English L, Anderson JAC, Maidment D, Huston DL (2008) An example of a Palaeoproterozoic back-arc basin: Petrology and geochemistry of the ca. 1864 Ma Stubbins Formation as an aid towards an improved understanding of the Granites-Tanami Orogen, Western Australia. Precambrian Research 166: 168-184.

Barovich K, Hand M (2008) Tectonic setting and provenance of the Paleoproterozoic Willyama Supergroup, Curnamona Province, Australia: Geochemical and $\mathrm{Nd}$ isotopic constraints on contrasting source terrain components. Precambrian Research 166: 318-337.

Bau M (1991) Rare-earth element mobility during hydrothermal and metamorphic fluid-rock interaction and the significance of the oxidation state of europium. Chemical Geology 93: 219-230.

Bierlein FP, Fuller T, Stüwe K, Arne DC, Keays RR (1998) Wallrock alteration associated with turbidite-hosted gold deposits. Examples from the Palaeozoic Lachlan Fold Belt in central Victoria, Australia. Ore Geology Reviews 13: 345-380.

Blake D, Hodgson I, Muhling P (1979) Geology of The Granites-Tanami Region. Bureau of Mineral Resources, Australia, Canberra Bulletin 197.

Blake D, Hodgson I, Smith P (1975) Geology of the Birrindudu and Tanami 1:250 0000 Sheet Areas, Northern Territory. Bureau of Mineral Resources, Australia, Canberra Report 174.

Cawood PA, Korsch RJ (2008) Assembling Australia: Proterozoic building of a continent. Precambrian Research 166: 1-35.

Claoué-Long J, Cross A, Smith J (2001) NTGS-AGSO Geochronology Project, Report 4. AGSO Record 2001/06.

Claoué-Long JC, Hoatson DM (2005) Proterozoic mafic-ultramafic intrusions in the Arunta Region, central Australia: Part 2: Event chronology and regional correlations. Precambrian Research 142: 134-158.

Condie KC, Wronkiewicz DJ (1990) The Cr/Th ratio in Precambrian pelites from the Kaapvaal Craton as an index of craton evolution. Earth and Planetary Science Letters 97: 256-267.

Crichton JG, Condie KC (1993) Trace elements as source indicators in cratonic sediments; a case study from the early Proterozoic Libby Creek Group, southeastern Wyoming. J. Geol 101: 319-332.

Crispe AJ, Vandenberg LC, Scrimgeour IR (2007) Geological framework of the Archaean and Palaeoproterozoic Tanami Region, Northern Territory. Mineralium Deposita 42: 3-26.

Cross A, Crispe AJ (2007) SHRIMP U-Pb analyses of detrital zircon: A window to understanding the Palaeoproterozoic development of the Tanami Region, northern Australia. Mineralium Deposita 42: 27-50.

Cullers RL, Podkovyrov VN (2000) Geochemistry of the Mesoproterozoic Lakhanda shales in southeastern Yakutia, Russia: implications for mineralogical and provenance control, and recycling. Precambrian Research 104: 77-93.

Dabard MP, Loi A, Peucat JJ (1996) Zircon typology combined with Sm---Nd whole-rock isotope analysis to study Brioverian sediments from the Armorican Massif. Sedimentary Geology 101: 243-260.

Dean A (2001) Igneous rocks of the Tanami Region. Northern Territory Geological Survey Record 2001-003.

Eggins SM, Woodhead JD, Kinsley LPJ, Mortimer GE, Sylvester P, McCulloch MT, Hergt JM, Handler MR (1997) A simple method for the precise determination of $>40$ trace elements in 
geological samples by ICPMS using enriched isotope internal standardisation. Chemical geology 134: 311-326.

Garzione CN, Patchett JP, Ross GM, Nelson J (1997) Provenance of Paleozoic sedimentary rocks in the Canadian Cordilleran miogeocline: a $\mathrm{Nd}$ isotopic study. Canadian Journal of Earth Sciences 34: 1603-1618.

Goleby BR, Huston DL, Lyons P, Vandenberg L, Bagas L, Davies BM, Jones LEA, Gebre-Mariam M, Johnson W, Smith T, English L (2008) The Tanami deep seismic reflection experiment: An insight into gold mineralization and Paleoproterozoic collision in the North Australian Craton. Tectonophysics In Press, Corrected Proof.

González-Álvarez I, Agnieszka Kusiak M, Kerrich R (2006) A trace element and chemical Th-U total $\mathrm{Pb}$ dating study in the lower Belt-Purcell Supergroup, Western North America: Provenance and diagenetic implications. Chemical Geology 230: 140-160.

Goodge J, Myrow P, Williams I, Bowring S (2002) Age and provenance of the Beardmore Group, Antarctica: Constraints on Rodinia Supercontinent break up. Journal of Geology 110 (4): 393-406.

Groves DI (1993) The crustal continuum model for late-Archæan lode gold deposits of the Yilgarn block, Western Australia. Mineralium Deposita 28: 366-374.

Hendrickx MA, Slater K, Crispe AJ, Dean AA, Vanderberg LC, Smith J (2000) Paleoproterozoic stratigraphy of the Tanami Region: regional correlations and relation to mineralizationpreliminary results. Northern Territory Geological Survey Record 2000-13.

Hodgson C (1993) Mesothermal lode gold deposits. Geol Assoc Can (Special Paper) 40: 635-678.

Huston D, Wygralak A, Mernagh T, Vandenberg IC, Crispe AJ, Lambeck A, Bagas L, Cross A, Fraser G, Williams N, Worden K, Meixner T (2007) Lode gold mineral systems of the Tanami Region, northern Australia. Mineralium Deposita 42: 175-204.

Lahtinen R (2000) Archean-Proterozoic transition: geochemistry, provenance and tectonic setting of metasedimentary rocks in central Fennoscandian Shield, Finland. Precambrian Research 104: 147-174.

Lahtinen R, Huhma H, Kouse J (2002) Contrasting source components of the Palaeoproterozoic Svecofennian metasediments: Detrital zircon U-Pb, Sm-Nd and geochemical data. Precambrian Research 116: 81-109.

Lally J, Worden K (2004) Geochronology in the Pine Creek Orogen-new results from NTGS. Annual Geoscience Exploration Seminar (AGES 2004) Record of Abstracts, Northern Territory Geological Survey Record 2004-001.

Lambeck A, Huston D, Maidment D, Southgate P (2008) Sedimentary geochemistry, geochronology and sequence stratigraphy as tools to typecast stratigraphic units and constrain basin evolution in the gold mineralised Palaeoproterozoic Tanami Region, Northern Australia. Precambrian Research 166: 185-203.

López JMG, Bauluz B, Fernández-Nieto C, Oliete AY (2005) Factors controlling the trace-element distribution in fine-grained rocks: the Albian kaolinite-rich deposits of the Oliete Basin (NE Spain). Chemical Geology 214: 1-19.

McLennan SM, Hemming S, McDaniel DK, Hanson GN (1993) Geochemical approaches to sedimentation, provenance and tectonics Geological Society of America Special Paper 284. pp 21-40.

McLennan SM, Hemming SR, Taylor SR, Eriksson KA (1995) Early Proterozoic crustal evolution: Geochemical and $\mathrm{Nd}---\mathrm{Pb}$ isotopic evidence from metasedimentary rocks, southwestern North America. Geochimica et Cosmochimica Acta 59: 1153-1177.

McLennan SM, Taylor SR (1982) Geochemical constraints on the growth of the continental crust. Journal of Geology 90: 347-361. 
McLennan SM, Taylor SR, McCulloch MT, Maynard JB (1990) Geochemical and Nd---Sr isotopic composition of deep-sea turbidites: Crustal evolution and plate tectonic associations. Geochimica et Cosmochimica Acta 54: 2015-2050.

Mernagh T, Wygralak A (2007) Gold ore-forming fluids of the Tanami region, Northern Australia. Mineralium Deposita 42: 145-173.

Michard A (1989) Rare earth element systematics in hydrothermal fluids. Geochimica et Cosmochimica Acta 53: 745-750.

Myers J, Shaw R, Tyler I (1996) Tectonic evolution of Proterozoic Australia. Tectonics 1: 14311446.

Nesbitt HW, Young GM (1984) Prediction of some weathering trends of plutonic and volcanic rocks based on thermodynamic and kinetic considerations. Geochimica et Cosmochimica Acta 48: 1523-1534.

Nesbitt HW, Young GM (1989) Formation and Diagenesis of Weathering Profiles. The Journal of Geology 97: 129-147.

Norrish K, Chappell BW (1977) X-ray fluorescence spectrometry. Academic Press, London.

Norrish K, Hutton JT (1969) An accurate X-ray spectrographic method for the analysis of a wide range of geological samples. Geochimica Cosmochimica Acta 33: 431-453.

Page RW, Sun S-S, Blake D (1995) Geochronology of an exposed late Archæan basement terrane in The Granites-Tanami region. AGSO Research Newsletter 22: 19-20.

Payne J, Barovich K, Hand M (2006) Provenance of metasedimentary rocks in the northern Gawler Craton, Australia: Implications for Palaeoproterozoic reconstructions. Precambrian Research 148: 275-291.

Plumb K, Ahmad M, Wygralak AS (1990) Mid-Proterozoic basins of the North Australia Cratonregional geology and mineralisation In: Hughes F (ed) Geology of the Mineral Deposits of Australia and Papua New Guinea. Australasian Institute of Mining and Metallurgy, Mongraph 14, pp 881-902.

Prame WKBN, Pohl J (1994) Geochemistry of pelitic and psammopelitic Precambrian metasediments from southwestern Sri Lanka: implications for two contrasting sourceterrains and tectonic settings. Precambrian Research 66: 223-244.

Pyke J (2000) Minerals laboratory staff develops new ICP-MS preparation method. AGSOGeoscience Australia Research Newsletter 33. Canberra, pp 12-14.

Robinson DM, DeCelles PG, Patchett PJ, Garzione CN (2001) The kinematic evolution of the Nepalese Himalaya interpreted from Nd isotopes. Earth and Planetary Science Letters 192: 507-521.

Roser BP, Coombs DS, Korsch RJ, Campbell JD (2002) Whole-rock geochemical variations and evolution of the arc-derived Murihiku terrane, New Zealand. Geological Magazine 139: 665-685.

Roser BP, Korsch RJ (1986) Determination of tectonic setting of sandstone-mudstone suites using $\mathrm{SiO}_{2}$ content and $\mathrm{Na}_{2} \mathrm{O} / \mathrm{K}_{2} 0$ ratio. Journal of Geology 94: 635-650.

Slack JF, Stevens BPJ (1994) Clastic metasediments of the Early Proterozoic Broken Hill Group, New South Wales, Australia: Geochemistry, provenance, and metallogenic significance. Geochimica et Cosmochimica Acta 58: 3633-3652.

Smith ME, Lovett DR, Pring PI, Sando BG (1998) Dead Bullock Soak gold deposits. Aust IMM Monogr 22:449-460 22: 449-460.

Taylor SR, McLennan SM (1985) The continental crust: its Composition and Evolution. Blackwell Scientific.

Tran HT, Ansdell K, Bethune K, Watters B, Ashton K (2003) Nd isotope and geochemical constraints on the depositional setting of Paleoproterozoic metasedimentary rocks along the margin of the Archean Hearne craton, Saskatchewan, Canada. Precambrian Research 123: 128. 
Tran HT, Ansdell KM, Bethune KM, Ashton K, Hamilton MA (2008) Provenance and tectonic setting of Paleoproterozoic metasedimentary rocks along the eastern margin of Hearne craton: Constraints from SHRIMP geochronology, Wollaston Group, Saskatchewan, Canada. Precambrian Research 167: 171-185.

Traves D (1955) The geology of the Ord-Victoria region, northern Australia. Bureau of Mineral Resources, Australia. Bulletin 27.

Tunks A (1996) Structure and origin of gold mineralization, Tanami Mine, Northern Territory. PhD thesis, University of Tasmania, Hobart.

Tunks A, Cooke D (2007) Geological and structural controls on gold mineralization in the Tanami District, Northern Territory. Mineralium Deposita 42: 107-126.

Ugidos JM, Valladares MI, Recio C, Rogers G, Fallick AE, Stephens WE (1997) Provenance of Upper Precambrian-Lower Cambrian shales in the Central Iberian Zone, Spain: evidence from a chemical and isotopic study. Chemical Geology 136: 55-70.

Wade BP, Hand M, Barovich KM (2005) Nd isotopic and geochemical constraints on provenance of sedimentary rocks in the eastern Officer Basin, Australia: implications for the duration of the intracratonic Petermann Orogeny. Journal of the Geological Society 162: 513-530.

Waight T, Maas R, Nicholls I (2000) Fingerprinting feldspar phenocrysts using crystal isotopic composition stratigraphy: implications for crystal transfer and magma mingling in S-type granites. Contributions to Mineralogy and Petrology 139: 227-239.

Waight TE, Weaver SD, Muir RJ, Maas R, Eby GN (1998) The Hohonu Batholith of North Westland, New Zealand: granitoid compositions controlled by source H20 contents and generated during tectonic tranition. Contributions to Mineralogy and Petrology 130: 225239.

Williams N (2007) Controls on mineralisation at the world-class Callie gold deposit, Tanami desert, Northern Territory, Australia. Mineralium Deposita 42: 65-87.

Yamashita K, Creaser RA, Villeneuve ME (2000) Integrated Nd isotopic and U-Pb detrital zircon systematics of clastic sedimentary rocks from the Slave Province, Canada: evidence for extensive crustal reworking in the early- to mid-Archean. Earth and Planetary Science Letters 174: 283-299. 